\title{
Contents
}

List of Illustrations vii

List of Contributors xii

1 The Global Crisis and the World: The Cases of Emerging and Developed Economies

Marin A. Marinov and Svetla T. Marinova

2 Foreign Direct Investment by Emerging Economy

Multinationals: Coping with the Global Crisis

Geraldine McAllister and Karl P. Sauvant

3 Outward FDI from the BRICs: Trends and Patterns of Acquisitions in Advanced Countries

Fabio Bertoni, Stefano Elia, and Larissa Rabbiosi

4 Internationalization of Central and Eastern European Countries and their Firms in the Global Crisis

Witold Wilinski

5 Information and Communication Technologies in the Globalization of Small and Medium-Sized Firms during the Global Crisis: An Empirical Study in China, India, New Zealand, and Singapore

Thomas Borghoff

6 An Analysis of the Macroeconomic Determinants of Indian Outward Foreign Direct Investment

Rakhi Verma and Louis Brennan

7 Influence of Cultural Distance on Chinese Outward Foreign Direct Investment

Rian Drogendijk and Katarina Blomkvist

8 Russia's Emerging Multinationals in the Global Crisis Sergey Filippov

9 Internationalization of Chinese Car Manufacturers Françoise Hay, Christian Milelli, and Yunnan Shi 
vi Contents

10 Location Determinants of Polish Outward Foreign Direct Investment and the Impact of the Global Crisis

Aleksandra Wassowska and Krzysztof Obłój

11 Reactions of Slovene Multinational Firms to the Global Crisis

Marjan Svetličič and Andreja Jaklič

12 Impact of the Global Crisis on the Internationalization of Estonian Firms: A Case Study

Tiia Vissak

13 Servicing Local Customers for Entering Foreign Markets: Internationalization of Russian IT Firms

Marina Latukha and Andrei Panibratov

14 Longitudinal Internationalization Processes of Born

Globals: Three Chinese Cases of Radical Change and the Global Crisis

Xiaotian Zhang and Jorma Larimo

Index 


\title{
2
}

\section{Foreign Direct Investment by Emerging Economy Multinationals: Coping with the Global Crisis*}

\author{
Geraldine McAllister and Karl P. Sauvant
}

\section{Introduction}

Even before the onset of the global crisis, the global market for foreign direct investment (FDI) had undergone significant changes. Foremost amongst these changes was the increasing importance of emerging market $^{1}$ multinationals (MNEs). While outward foreign direct investment (OFDI) from these markets is, in itself, not new, the magnitude that this phenomenon achieved prior to the crisis and its resilience in the face of the global crisis suggest that this is not a temporary occurrence but rather a sign of a fundamental change that is taking place in the global OFDI market. However, emerging markets are not homogenous: in addition to the rise in OFDI from emerging markets, the formation of new regional groupings has led to the emergence of fresh investment patterns. This chapter examines changes taking place in global FDI flows and looks at the impact of the crisis in the context of profound structural changes; it also focuses on the response of emerging markets and the enormous risks and challenges that lie ahead. It is vital to note that this crisis is ongoing, and it is too early to predict the final contours it will leave in its wake on the FDI landscape.

\section{Changing patterns of OFDI: Beyond the global crisis}

\section{Changing patterns of OFDI}

The rise of global OFDI over the past three decades has been remarkable. Prior to the crisis, global OFDI flows had grown by a factor of

\footnotetext{
*This text builds on Sauvant et al. (2010).
} 


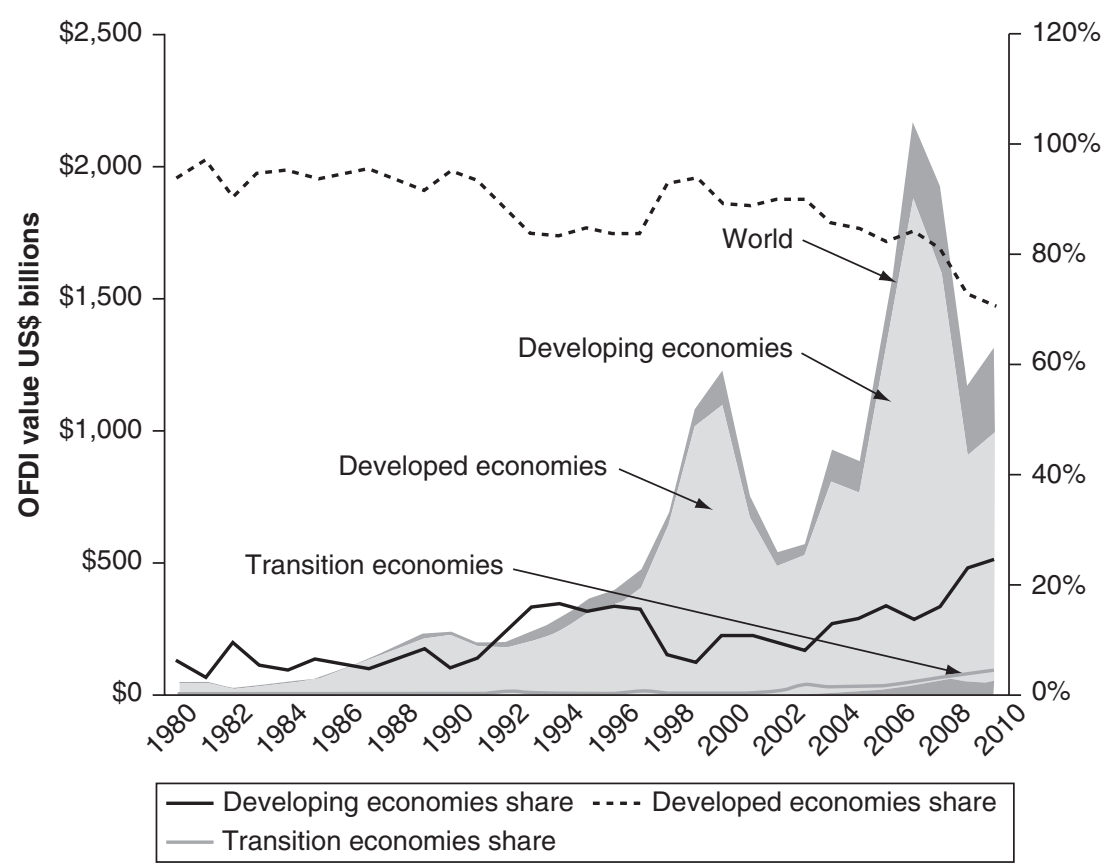

Figure 2.1 FDI outflows, globally and by group of economies, 1980-2010 (US\$ billions)

Source: Authors, based on data from unctadstat.unctad.org.

40 in less than three decades, from a yearly average of US\$ 47 billion in 1980-1985, to US\$2.2 trillion in 2007 (Figure 2.1 and Table 2.1). Since peaking in 2007, OFDI flows have declined significantly. Nevertheless, at US\$1.2 trillion, average OFDI flows for the five-year period 2003-2007 were almost 40 per cent higher than in the period 1998-2002, when they averaged US $\$ 860$ billion.

Even more remarkable has been the rise in OFDI from emerging markets in recent years, ${ }^{2}$ and its ability to withstand the worst of the global crisis. From less than 5 per cent of OFDI flows in 1990, emerging markets accounted for almost 30 per cent of OFDI flows in 2010 (Figure 2.2), a trend that showed no sign of changing in 2011 too. (UNCTAD, 2011a). In terms of inward foreign direct investment(IFDI), the performance of emerging markets has been equally impressive. The share of inward investment flows rose from 17 per cent in 1990, to no less than 50 per cent each year until 2009, reflecting an average annual growth of 12 per cent since 2000 (UNCTAD, 2012b). 


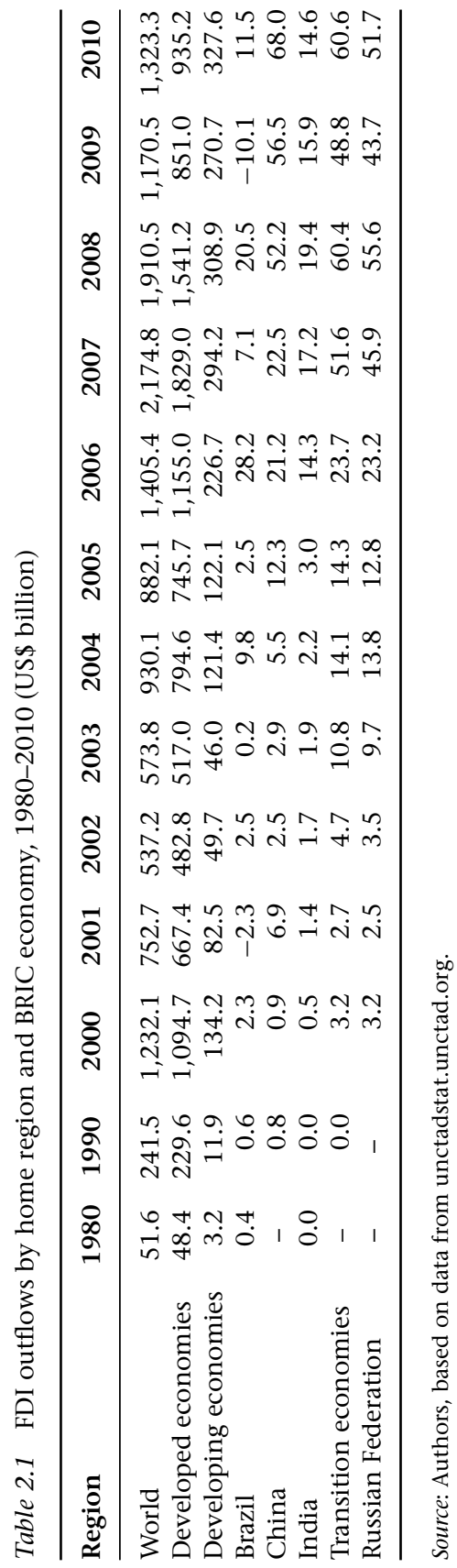




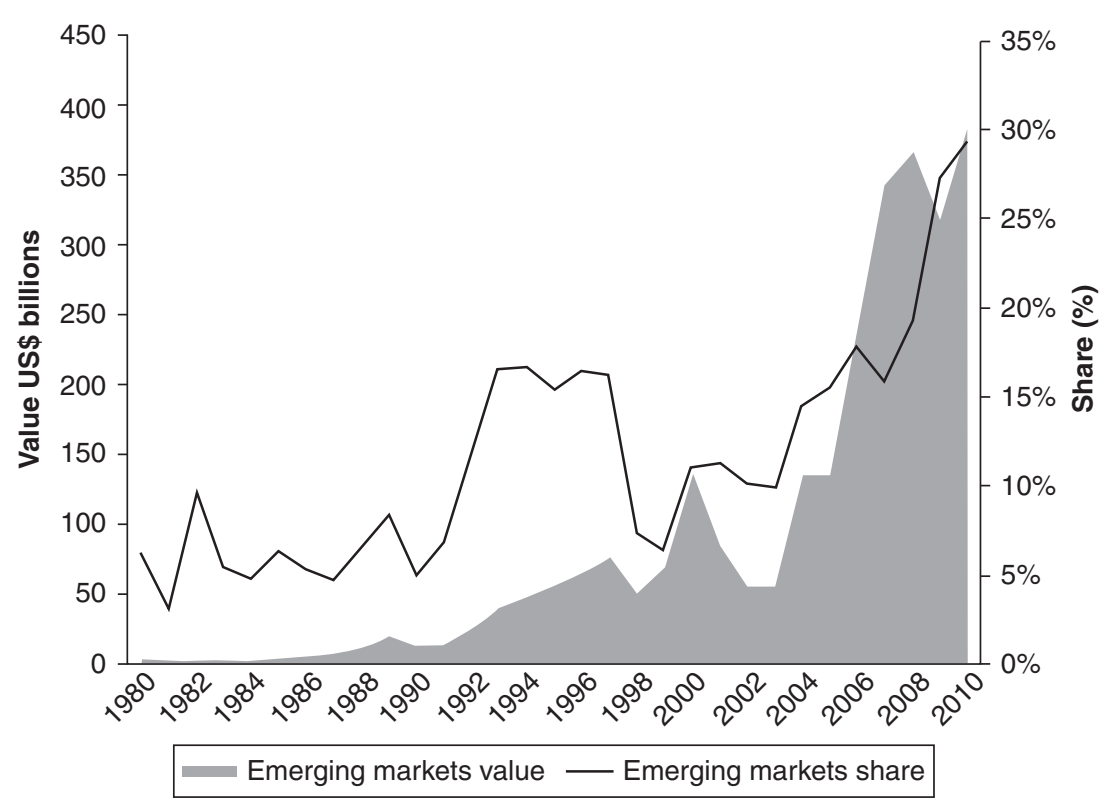

Figure 2.2 Emerging markets OFDI, value and share, 1980-2010 (US\$ billions \%) Source: Authors, based on data from unctadstat.unctad.org.

\section{The changing FDI landscape: Beyond the global crisis}

To date, the focus has been on the immediate impact of the crisis, as measured by the value of OFDI flows. The dramatic increase in these flows till 2007 and their subsequent decline, however, is one of the visible aspects of the fundamental changes that are reshaping the global market for FDI. A number of these changes were perceptible prior to 2007-2008; the main impact of the crisis has been on their rate of change. Other changes stem directly from the crisis, but are likely to continue even when the world economy returns to robust health.

\section{Number of MNEs}

The ongoing economic crisis has halted or even reversed years of economic growth in many countries and slowed the rate of growth in others. Its impact on the trend toward an increasingly integrated world economy has been more limited, however, and, in many instances, the domestic downturn has spurred firms to seek growth opportunities abroad. The significant increase in the number of MNEs, despite 
the recent years of economic turmoil, reflecting this trend. From about 70,000 MNEs in 2004, with about 690,000 foreign affiliates, there are over 100,000 MNEs in existence today, with more than 890,000 foreign affiliates (UNCTAD, 2005: xix; UNCTAD, 2011, annex table 34).

The geographical distribution of these MNEs and their foreign affiliates underlines the increasing integrated and competitive nature of the world economy, requiring MNEs everywhere to develop a portfolio of locational assets if they are to compete successfully in the global economy. In 2010, over 30,000 parent corporations were based in emerging markets, a whole 30 per cent of the total (UNCTAD, 2011, annex table 34). Emerging markets were host to over 500,000 foreign affiliates (58 per cent of the total), a 17 per cent increase on 2004 (ibid., UNCTAD, 2005: xix). Developed economies were host to more than 370,000 foreign affiliates (42 per cent of the total), a figure that has grown by over 50 per cent since 2004 (ibid.).

\section{A new Triad?}

The increasing importance of OFDI by emerging market MNEs is the latest discernible pattern in global OFDI. In a global market once dominated by the US and the European Union (EU), this duopoly gave way to the Triad of the US, EU, and Japan. This Triad declined, as Japan entered a prolonged period of economic stagnation, and is often referred to as 'Old Triad.' The rise in OFDI from emerging markets has contributed to the appearance of a 'New Triad' consisting of the US, the EU, and emerging markets (see Figure 2.3). Yet, Figure 2.3 reveals that this New Triad's share of global OFDI stocks was, in fact, higher in the early 1980s, underlining the frequently short-lived nature of such trends. Moreover, we may well move beyond a world of Triads. Economou and Sauvant (2011) look to the possible emergence of a 'multi-polar FDI world ... in which smaller poles coexist with the dominant members of the former Triad,' (2011: 2). The World Bank envisions 'a new world order with a more diffuse distribution of economic power...the shift toward multipolarity' (The World Bank, 2011: xi).The changing origins of OFDI is only one part of the picture; the sectors into which OFDI flows is also undergoing change.

\section{Sectoral change}

The sectoral composition of global OFDI stock has changed considerably over recent decades and the service sector has assumed greater importance, aided by innovation and deregulation, as well as advances 


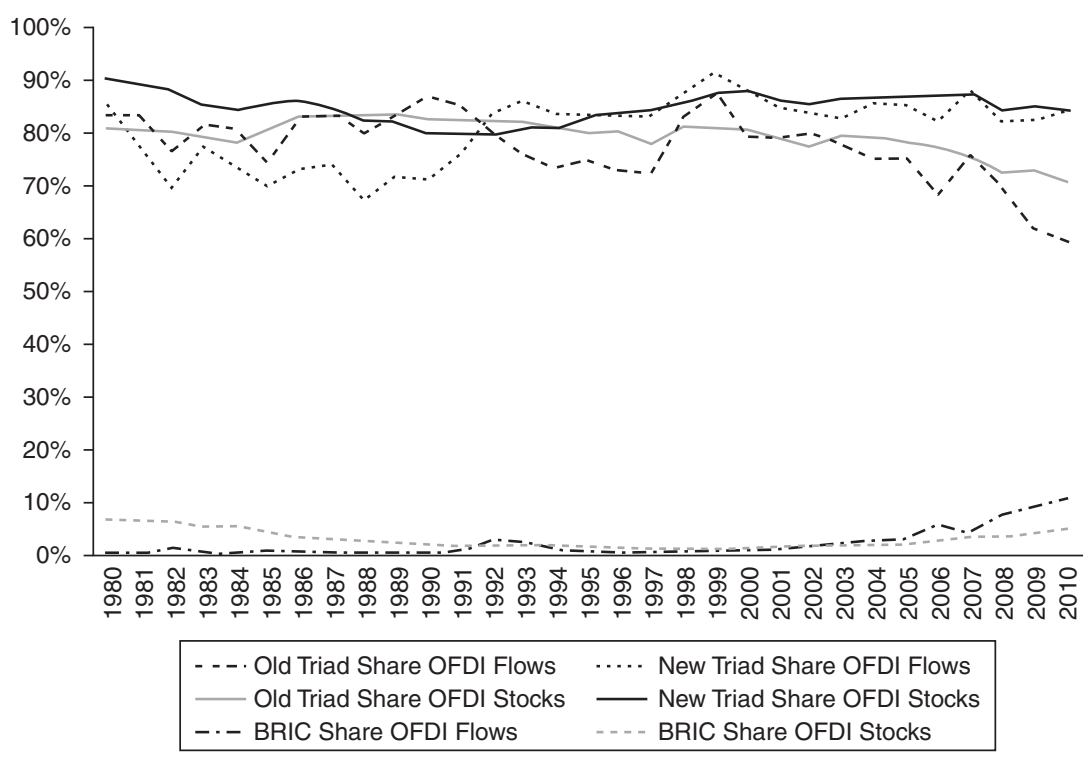

Figure 2.3 Old and New Triad, and BRICS share of global OFDI, 1980-2010 (\%) Source: Authors, based on data from unctadstat.unctad.org.

in information communications technology (ICT). In 1990, the service sector accounted for almost half of global OFDI stock, a share that had risen to two-thirds by 2009. Interestingly, over this period the share of finance within the service sector remained relatively constant, at 24 per cent in 1990 to 26 per cent in 2009 (UNCTAD, 2011, annex table 25). Almost all of the growth recorded, occurred within business activities, and was the result of a shift in management practices toward core activities, and technological advancements that facilitated the off shoring and outsourcing of various business support functions. The share of the primary sector in global OFDI stock declined only slightly over this period, from 9 per cent in 1990 to 8 per cent in 2009, as MNEs continued to seek secure access to finite reserves of natural resources (ibid.). Manufacturing, however, declined significantly, from 43 per cent of global OFDI stock in 1990, to only 24 per cent in 2009 (ibid.).

This picture is repeated across developed economies, where the share of the primary sector fell from 9 per cent in 1990 to 8 per cent in 2009 (ibid.). The services sector rose from 48 per cent to 64 per cent over this period, the result of increase in business services (ibid.). At the global 
level, the share of manufacturing declined from 43 per cent in 1990 to 26 per cent in 2009 (ibid.).

The picture for emerging market OFDI is very different, and rather surprising. Both the primary and manufacturing sectors shrank significantly over the period 1990-2009, from 13 per cent to 6 per cent, and from 36 per cent to 11 per cent, respectively (ibid.). The service sector, which was the principal sector in 1990 accounting for 51 per cent of total OFDI stock, was dominating the scene by 2009, accounting for 79 per cent of OFDI stock, driven by growing OFDI in business services (ibid.). This is explained largely by significant investment in business activities in Hong Kong and China..$^{3,4}$

The dramatic impact of the financial crisis and the ongoing global crisis continue to affect the investment choices and decisions of MNEs. For some, the need to reduce their debt burden has forced them to dispose whole divisions, creating an opportunity for others to capitalize on. Nevertheless, the sheer scale of the financial crisis and uncertainty over the shape of ongoing reform has resulted in the decline of investment in the service sector (Figure 2.4), and, in 2010, manufacturing accounted for almost 50 per cent of total investment in FDI projects.

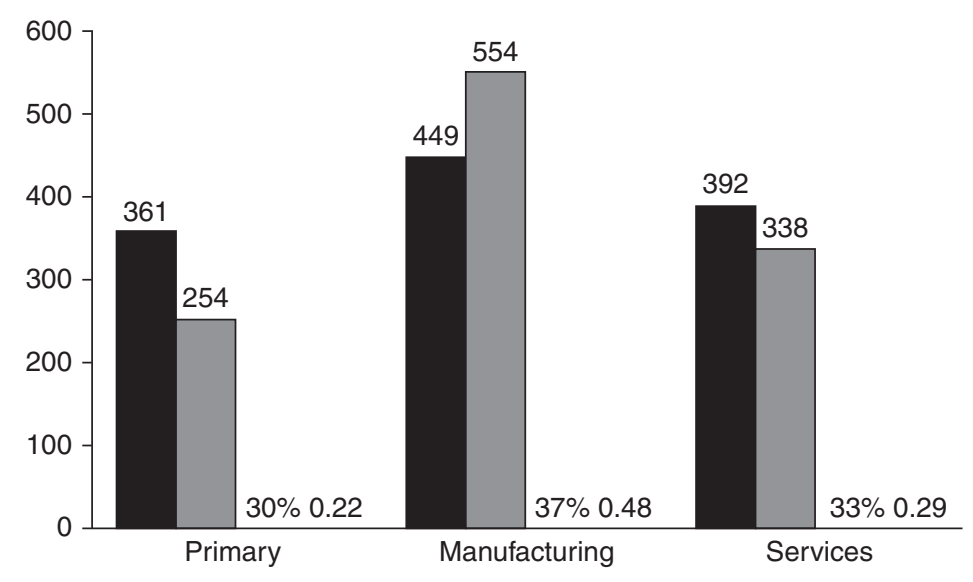

$2009 \square 2010 \square$ Share $2009 \square$ Share 2010

Figure 2.4 Sectoral distribution of FDI projects, 2009-2010 (US\$ billions, \%) Source: UNCTAD (2011: 9). 


\section{Mode of investment}

Levels of mergers and acquisitions (M\&As) and greenfield investment, the principal vehicles for FDI, highlight the dramatic changes taking place in the global FDI market (Figure 2.5).

Total M\&A activity peaked in 2007 at US $\$ 1$ trillion, more than double the average of the previous decade (Figure 2.6). From 2008, however, as markets became illiquid and firms adopted a 'wait and see' approach to investment, M\&A activity declined sharply, to US\$250 billion in 2009, one quarter of the previous high. A gradual recovery took place in 2010, but at US\$339 billion, total M\&A activity was only one-third the level of 2007.

The decline in M\&As was most pronounced in developed economies. From a high of US\$842 billion in 2007, the total value of M\&As had fallen 80 per cent, to US $\$ 161$ billion by 2009 (UNCTAD, 2011, annex table 10). Growth resumed in 2010, but at US\$216 billion, the total value of M\&As undertaken by developed countries was one quarter of its 2007 high (ibid.).

Emerging markets have weathered the crisis better. From a high of US $\$ 167$ billion in 2007, the total value of M\&As declined 51 per cent to US $\$ 81$ billion in 2009 (ibid.). As in developed countries, growth resumed in 2010, and by the end of the year the total value of M\&As was almost two-thirds of its 2007 high, at US $\$ 106$ billion (ibid.).

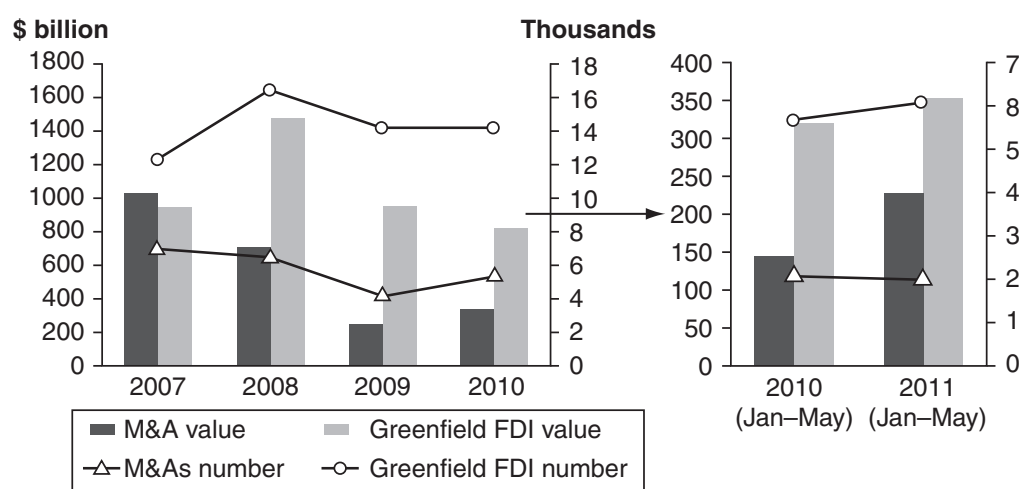

Figure 2.5 Value and number of cross-border M\&As, and greenfield FDI projects, 2007-2011 (May)

Note: Data for value of greenfield FDI projects refer to estimated amounts of capital investment.

Source: UNCTAD (2011: 11). 


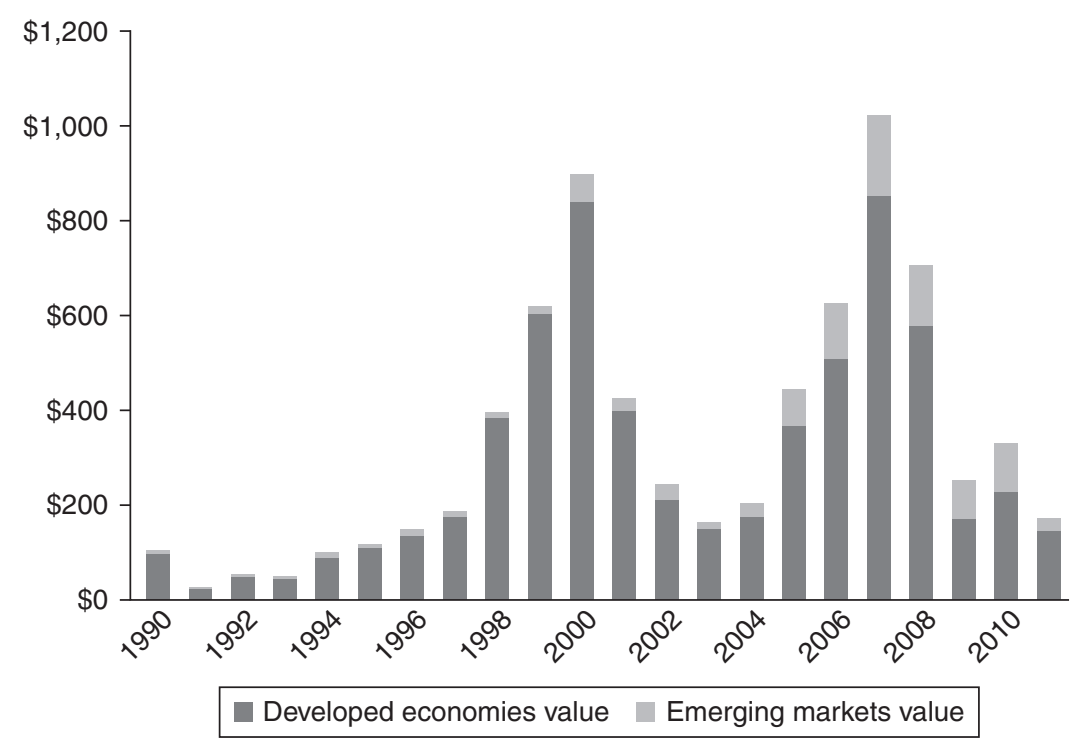

Figure 2.6 Total M\&A value by purchase region, 1990-2011 (May) (US\$ billions) Source: Authors, based on data from UNCTAD (2011, annex table 10).

In terms of M\&As, the shift in activity from developed economy MNEs to emerging market MNEs has gained momentum since the beginning of the crisis. Emerging markets accounted for only 10 per cent of all M\&A activity in the 1990s, a share that rose to 17 per cent in the 2000s (ibid.). By 2010, one-third of all M\&A activity was taken over by emerging market MNEs (ibid.).

Greenfield investments, which was by nature slower to react to changing economic circumstances, continued to grow through 2008, and reached a high of US $\$ 1.5$ trillion, an 80 per cent increase on the average of the previous five years (Figure 2.7) (UNCTAD, 2011, annex table 18). They declined in 2009 and 2010, but the decline was less dramatic to that of M\&As; at US\$807 billion in 2010, the levels of greenfield investments were at 55 per cent in 2008 , and in line with the average for the period 2003-2007, at US\$801 billion.

The pattern of total greenfield investments since 2003 reflected also in the levels in both developed economies and emerging markets. Developed economies' greenfield investments peaked in 2008 at US\$1 trillion, a rise of 60 per cent on 2007, before falling back to US\$569 billion in 2010, a drop of 45 per cent (UNCTAD, 2011, annex table 18). Emerging markets' greenfield investment rose by 58 per cent in 2008 to reach a high of US\$434 billion, and declined to 45 per cent over the next two 


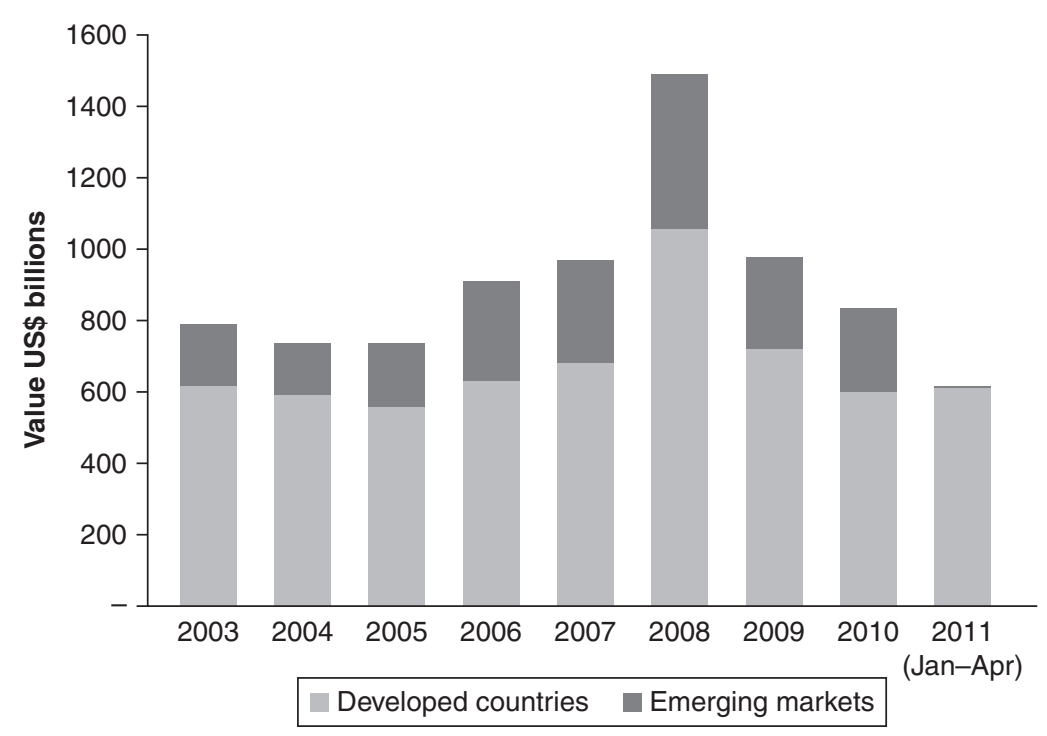

Figure 2.7 Value of greenfield projects by source, 2003-2011 (May) (US\$ billions) Source: Authors, based on data from UNCTAD (2011, annex table 18).

years to US $\$ 238$ billion (ibid.). Nevertheless, over the course of the past decade, the share of emerging markets has increased gradually: From 23 per cent in 2003, it stood at 29 per cent by 2010 (ibid.).

\section{Emerging markets: Coping with the crisis}

The crisis that began in the banking and financial systems of the US and Europe in 2007, spread rapidly and spared few economies. Emerging markets have not escaped the crisis, but most have displayed greater resilience than developed economies, emerging earlier from the downturn, thereby strengthening their relative position in the global economy. That this has occurred less than a decade after a crisis had swept through Asia, Russia, Latin American, and Turkey, a decade that saw these economies become more closely integrated into the global economy, raises the question of how this group of economies has achieved this.

\section{Coping strategies}

The term 'emerging markets' encompasses a large, diverse group of economies, affected in different ways and to different degrees by the global crisis. In this section, we will examine the impact of the global 
crisis on four key emerging markets: Brazil, Russia, India, and China, and examine how they have responded to, and coped with, it. We will consider the state of the economy at the onset of the crisis; the impact of the crisis on the economy and outward investment of MNEs; policy measures adopted in response to the crisis; and their success to date.

\section{Brazil}

Brazil, the largest economy in Latin American, enjoyed strong annual growth from 2000 to 2008, averaging 3.7 per cent, driven, in large part, by high commodity prices and increasing exports to China (UNCTADSTAT, 2012). Over this same period, the OFDI stock of Brazil more than tripled from US\$54 billion to US\$ 156 billion (ibid.).

The global crisis touched first on Brazil's financial markets. By the end of 2008, the value of the stock market had halved, and the real value of stocks depreciated as investors sought safe havens (Trading Economics, 2012). The crisis moved quickly to the broader economy. Foreign investment declined, commodity prices fell, and exports volumes declined as growth in Brazil's export markets, particularly its largest export market, China, slowed.

The Brazilian Government responded quickly to the crisis. In December 2008, it had launched a US\$20 billion stimulus package, equivalent to 1.2 per cent of GDP, extending the Growth Acceleration Program of 2007 (Congressional Research Service, 2009: 75). The program included investments in infrastructure, tax cuts and measures to maintain household income, intended to shore up domestic demand. It was largely successful, and the large domestic market and stronger demand helped mitigate the effects of the global crisis on the economy. After contracting by 0.2 per cent in 2009, the economy grew by 7.5 per cent in 2010, one of the highest annual rates of growth since 1986 (OECD, 2010: 195).

OFDI activity by Brazilian MNEs was also curtailed during the crisis, and flows fell from US\$20 billion in 2008, to minus US\$10 billion in 2009 , as intra-company loans were repaid, in order to shore up parent companies during the height of the crisis (ECLAC, 2009; UNCTAD, 2011). Growth resumed in 2010, and at US\$11.5 billion, OFDI flows were just over half of their 2008 high (ibid.). However, the outlook for 2011 looks less positive, with concerns that high levels of intercompany loan repayment by foreign affiliates will result in negative outflows once again (see UNCTAD, 2011: 60). The higher than usual levels of intercompany-loan repayment may be the result of efforts to shore up parent companies, or it may be one solution to limited access to financing domestically. Unusual, as it is to see affiliates helping the 
activities of their parent companies, this underlines the importance of OFDI to the continued success of Brazilian MNEs.

\section{Russia}

The 1980s and 1990s were a particularly turbulent period for the Russian economy, but that appeared to change in 1999, when Russia entered a decade of dynamic growth averaging 8 per cent per annum, driven largely by rising energy prices and a domestic lending boom (UNCTADSTAT). By 2007, Russia's foreign-held debt, including inherited Soviet-era debt, was paid down and the government debt to GDP ratio was only 7 per cent (The World Bank, 2012).Total financial assets were equivalent to only 68 per cent of GDP); there was a regular budget surplus, and foreign reserves totaled US\$597 billion by mid-2008 (Nanto, 2009: 96). Over this period, Russian OFDI grew dramatically, from US\$2 billion in 1999 to US\$56 billion in 2008 (UNCTADSTAT). OFDI stock rose from US\$9 billion in 1999, to US\$370 billion by 2007 (ibid.).

The global crisis brought this decade of growth to an abrupt end. The fall in global demand caused commodity exports to fall and prices to collapse-extremely damaging for an economy in which ten of the twenty largest non-financial outward investors ${ }^{5}$ are in the oil and gas, or metal industries (IMEMO-VCC, 2011: 2). More than half the value of the Russian stock exchange was wiped out between July 2008 and July 2009, as nervous investors withdrew (Financial Times, 2008: 13), and a weak banking system and tighter credit reduced domestic demand (Filippov, 2011). From growth of 8.5 per cent in 2007, the economy shrank by 7.8 per cent in 2009 (UNCTADSTAT). Over this same period, Russian OFDI stock also declined. Having grown 18-fold between 2000 and 2007 to a total of US\$370, it fell by 44 per cent in 2008 to US\$206 billion (UNCTADSTAT), reflecting a fall in the value of foreign assets, and firms pulling back after a period of rapid expansion (Panibratov and Kalotay, 2009). However, the downturn in 2008-2009 did not signal the beginning of an extended period of economic decline: The economy and OFDI both returned to growth in 2010, growing 4 per cent and 50 per cent, respectively (UNCTADSTAT).

How has Russia succeeded in coping with this global crisis, only a decade after a more-limited crisis forced the government to devalue its currency and default on its debt? One of the critical differences is that this was not a crisis solely of Russia's making and, as a result, its economy was less directly impacted than the economies of developed countries in whose banking systems the crisis had its roots. Strong global 
growth before the crisis kept commodity prices high, allowing Russia to accumulate almost US\$600 billion in currency reserves (Nanto, 2009: 96), including US $\$ 130$ billion in the Stabilization Fund of the Russian Federation, created in 2004 (Ministry of Finance of the Russian Federation, 2012). As a result, the authorities enjoyed much greater 'space' in which to develop emergency policies in response to the crisis. The IMF estimates at 10.5 per cent of GDP the loosening that occurred in Russia's primary balance over 2008-2009 (IMF, 2010: 29), used to shore up the domestic economy through loans to banks, government purchase of stocks, emergency loans to strategically important firms, and a lowering of the corporate tax rate. Yet, not all efforts were successful: Attempts to support the ruble failed, at an estimated cost of US\$200 billion (IMF, 2010: 28) and, finally, it was allowed to devalue.

The crisis highlighted structural weaknesses in the Russian economy: an over-reliance on the oil and gas and metal industry, and a weak banking sector. Yet, the government has done little to diversify economic activity; focusing resources on a small number of state-controlled firms further hampers private firms' access to capital (Nanto, 2009; Filippov, 2011). Finally, the government response has been criticized for its opacity (Jellinek, 2009; Wisniewska et al., 2010; Filippov, 2011) with concerns that support went primarily to firms deemed strategically important, while failing to develop clear policies to support OFDI by Russian MNEs.

\section{India}

The years 2000 to 2010 saw India enjoy average annual growth of 7.9 per cent, its highest decade of growth since 1970 (UNCTADSTAT), driven largely by growing domestic demand. With the gradual liberalization of the economy from the 1990s onward, India became more closely integrated into the global economy through trade and capital flows, a trend that is reflected in the rapid growth of OFDI by Indian MNEs. ${ }^{6}$ From US $\$ 1.4$ billion in 2001, OFDI flows exceeded US\$19 billion in 2008 (UNCTAD, 2011). In 2009, seven Indian MNEs featured among the top-100 non-financial MNEs of emerging markets (UNCTAD, 2011, annex table 30), in industries as diverse as metal and metal products and consulting services. Only one of the seven firms, Oil and Natural Gas Corporation Limited, is state-owned, reflecting the dominant role of the private sector in Indian OFDI.

As the home-country policy framework changed, so have the patterns of Indian OFDI. From an early concentration in manufacturing and an emphasis on south-south investments prior to 1991, Indian OFDI shifted toward investment in services, increasingly in developed 
economies (Kumar, 2007). Deregulation spurred growth in the domestic economy, underlining the importance of securing access to natural resources. Between 2000 and 2007, 25 per cent of Indian OFDI was in the primary sector, with 40 per cent in manufacturing, and 35 per cent in services (Pradhan, 2011b). Hand in hand with this shift, OFDI by Indian MNEs increasingly took place through M\&As in developed economies. Between 2000 and 2009, 58 per cent of all OFDI by Indian MNEs was in developed economies: Europe received 41 per cent of OFDI flows and North America 10 per cent, with 21 per cent in South-Eastern Asia (Pradhan, 2011a: 125, 127).

The greater openness of the Indian economy, with globalization acting as an accelerator in good economic times, lessened its resistance to the global crisis. From 9.6 per cent in 2007, the rate of growth of the Indian economy almost halved to 5.1 per cent in 2008, as exports fell and capital flows declined (UNCTADSTAT). The credit freeze limited access to overseas borrowing, a critical source of funding for crossborder M\&As, and OFDI flows declined significantly. From a high of US $\$ 19$ billion in 2008, OFDI flows from India fell by 18 per cent, to US\$16 billion in 2009 (UNCTAD, 2011).

The Government responded swiftly to the global crisis through a combination of fiscal and monetary policy measures; its efforts focused on shoring up aggregate demand and maintaining liquidity. With domestic demand driving growth in the Indian economy, the downturn was short-lived (Pradhan, 2011b). The rate of growth picked up in 2009, reaching 7.7 per cent that year, and 8.5 per cent in 2010 (UNCTADSTAT). Yet, as the global downturn continued with developed economies worst affected, OFDI registered a further 8 per cent decline in 2010, falling to US\$14.6 billion (UNCTAD, 2011).

\section{China}

China is the largest emerging market and, since 2011, the world's second largest economy, following three decades of average annual growth approaching 10 per cent, driven by the industrialization of the economy and its increasing openness to trade and foreign investment. Between 2000 and 2007 alone, annual growth averaged 10.5 per cent (UNCTADSTAT). OFDI by Chinese MNEs has also grown rapidly. From less than US $\$ 40$ million in 1981, OFDI stocks totaled US148 billion in 2008, a 54 per cent increase on 2007 (UNCTAD, 2011). OFDI flows more than doubled from 2007 to 2008 , to US $\$ 52$ billion (ibid.). As a result of its growing trade surpluses and FDI, China's holdings of foreign reserves have increased dramatically, totaling US\$1.6 trillion (excluding gold) 
before the crisis (end 2007) and US\$2.8 trillion at the end of 2010 (The People's Bank of China, 2008, 2010).

Despite its record of strong growth, the importance of trade and FDI to the Chinese economy exposed it to the recession in its largest export markets, the European Union and the US. By May 2009, exports were less than three-quarters of their level of the previous year (Congressional Research Service, 2009: 75). Inward FDI flows (IFDI), having doubled since the beginning of the decade, fell by 12 per cent in 2009 (UNCTADSTAT). The rate of growth of OFDI flows fell rapidly, from 132 per cent in 2007-2008, to 8 per cent in 2008-2009 (ibid.), but in a context in which world FDI flows halved. The impact on unemployment was swift, with the government estimating that 20 million migrant workers had lost their jobs in 2008 because of the crisis (Congressional Research Service, 2009: 75).

The Chinese authorities acted swiftly to mitigate the effects of the crisis on the domestic economy, launching a US\$586 billion stimulus package in November 2008, equivalent to 12 per cent of GDP (Congressional Research Service, 2009: 75). The scale of the stimulus package and the speed with which it was announced, ahead even of the US announcement of a US\$787 stimulus package in February 2009 (Recovery.gov), indicated the authorities' level of concern over the impact of the crisis on the Chinese economy. Their aim was to maintain aggregate demand through increased spending on infrastructure and social welfare, and tax deductions on capital spending by firms (Nanto, 2009). Monetary policy measures were also adopted: after a period of strengthening, the $\mathrm{RMB}$ was allowed to depreciate, interest rates and reserve requirements were lowered, and lending by state banks was eased (De Beule and Van Den Bulcke, 2010). Furthermore, the government sought to support OFDI by Chinese firms, by simplifying the approvals process, for example, and reducing restrictions on firms' lending to their affiliates (ibid.).

The measures adopted by the Chinese authorities in response to the global crisis were largely successful, sparing the economy from its worst effects. Growth, which had fallen from 14 per cent in 2007 to 9.2 per cent in 2009, exceeded 10 per cent in 2010 (World Bank Indicators). The rate of growth of OFDI picked up: From 8 per cent in 2008-2009, it reached 20 per cent in 2009-2010 (UNCTAD, 2011). By 2010, China's OFDI stock totaled US\$298 billion, double their 2008 level (ibid.), as Chinese firms, unhindered by the credit crisis and taking advantage of lower asset prices, made a large number of acquisitions. Despite the apparent success of the policies implemented in mitigating the impact 
of the crisis on the economy, concerns remain. While the measures implemented have helped Chinese firms weather the storm in the short term, will state-control hamper their ability to pursue policies based on economic objectives in the longer term? (De Beule and Van Den Bulcke, 2010).

\section{The BRIC economies}

The BRIC group of economies and the OFDI activities of their MNEs have shown great resilience in the face of the global crisis. As the crisis hit, MNEs responded by scaling back their OFDI: From a high of US $\$ 148$ billion in 2008, OFDI flows fell by 14 per cent in 2009, to US $\$ 126$ billion (UNCTADSTAT). Nevertheless, by 2010, activity had returned to pre-crisis levels and the combined OFDI flows from the BRIC economies totaled US $\$ 146$ billion, 99 per cent of their record 2008 level (ibid.). In 2010, they accounted for 11 per cent of global OFDI flows, a dramatic increase on their 1 per cent share in 2000 (ibid.). For the first time, the combined OFDI stock of the BRIC group exceeded US $\$ 1$ trillion in 2010, 5 per cent of the global OFDI stock (ibid.). This represented an almost tenfold increase on 2000, when their OFDI stock totaled slightly more than US $\$ 100$ billion (ibid.).

There are a number of reasons for the resilience of these emerging markets and the OFDI activities of their MNEs in the face of the worst global crisis since the 1930s. The global crisis began in the financial markets of developed economies, where more than two decades of deregulation had reduced considerably levels of oversight and control at a time of great innovation in financial products. This was not the case in emerging markets, where the harsh lessons learned from the emerging markets crisis of the 1990s were still fresh. Governments in these economies have maintained a much greater role in the operation and supervision of financial markets. In addition, total levels of debt, especially foreign currency denominated debt, were low, and sustained budget surpluses combined with high levels of FDI, enabled governments to accumulate significant foreign currency reserves. Despite some initial weakening, therefore, emerging market currencies generally remained strong, limiting the impact of the crisis on the domestic economy.

High levels of growth in emerging markets are often attributed to the important role of exports in their economies. Exports are indeed important but their relative importance is declining. Instead, it is their strong domestic demand, with high levels of consumption and investment that has supported high growth rates in most emerging markets, and insulated them from the worst of the crisis. High savings rates and bank 
deposits have supported domestic lending; critically, bank lending did not decline at the onset of the crisis. The authorities did not raise interest rates, and in a number of economies, including India, interest rates were lowered.

Emerging markets have benefited from the dominance of FDI in their private capital flows, generally considered a more stable form of capital than portfolio investment or other forms of debt finance such as loans and bonds. However, even FDI is not quite as stable a form of capital as it once was considered to be, as its composition also shifts from mainly equity to debt in the form of intra-company loans. The risks associated with this are seen in the OFDI from Brazil, which is expected to decline or become negative in 2011, the result of higher than usual levels of intra-company loan repayment (UNCTAD, 2011: 60). There are a number of possible explanations for this: Weaker performance in the home market may have reduced profitability, or access to capital may have become more limited; but the fact that foreign affiliates are shoring up their parent companies further underlines the importance of OFDI.

OFDI by emerging market MNEs has taken the form of greenfield investment for the most part, while developed country MNEs have relied more on M\&As. The latter are more vulnerable to shocks to the financial system and, as liquidity and funding dried up, the number of M\&As undertaken by developed economy MNEs fell rapidly. Emerging market MNEs, especially relatively young firms, have not enjoyed the same access to international capital markets, and they and their OFDI activities consequently suffered less. In those instances in which emerging market MNEs do engage in cross-border M\&As, they are more likely to pay for them in cash rather than in shares (World Bank, 2011: 83-84), a decision linked to the ownership nature of these firms and the limitations of their domestic capital markets. Emerging market firms are more likely to be family or state-controlled entities that seek to avoid any dilution of their control, and so prefer to pay for acquisitions in cash (ibid., Resende et al., 2010).

Finally, the strong performance of emerging markets and their MNEs highlights how critical it is to maintain strong economic fundamentals. Thanks to their sound economic management pre-crisis, with large foreign exchange reserves and low levels of national debt, these governments had the necessary 'policy space' to implement emergency measures to shore up their economies during turbulent economic times. 


\section{Global players from emerging economies: challenges ahead}

In the immediate aftermath of the crisis, the attentions of key actors were focused on responding to its most pressing challenges and, to date, these efforts have proven relatively successful. By the end of 2010, OFDI flows from emerging market MNEs had reached a new high of US\$388 billion (UNCTADSTAT). Inward investment to emerging markets has also made a strong recovery, reaching US\$753 billion in 2011, 97 per cent of its 2008 high (UNCTAD, 2012). However, numerous other challenges persist, some inherent in the rise of these new global players, others resulting from the ongoing economic crisis. This section addresses a number of these risks and challenges, and considers the path ahead.

\section{Key strategic challenges for emerging market MNEs}

Perhaps the single most important challenge that emerging market MNEs face relates to their human resources. Building a successful, integrated international production network is a formidable challenge, to do so through the successful integration of acquired firms amplifies the difficulties. It places considerable demands on their human resources, in particular on their managerial skills and capacity. Moreover, the scale of the challenge is relatively higher for emerging market MNEs: Internationalizing often at an early stage in their development (and more recently), they have had less time to develop such skills and capacities. Those emerging markets that have a longer and greater experience with OFDI have distinct advantages in this area, having been able to develop management skills, expertise, and an understanding of international markets (Jaklič and Svetličič, 2010).

Emerging markets MNEs that have undertaken OFDI more recently are less likely to have built up expertise and capacity in integrating acquisitions and managing foreign affiliates, a gap that may be further compounded by an unwillingness to hire non-national managers. An example is Brazil, where the level of foreign managerial employment among leading MNEs is almost half that of the 100 largest developing country MNEs (Resende et al., 2010: 104). Family-controlled MNEs seek to avoid any dilution of their control and high levels of 'in-group collectivism' (ibid.), and such practices complicate further the building of international management networks and do not bode well for the ability of those MNEs to create integrated international production networks. 
There are also broader challenges to be met. MNEs face the continuous challenge of balancing opportunities and risks. The rapid pace of globalization and industry consolidation has led in many cases to a mind-set of 'hunt or be hunted' (Price Waterhouse Coopers, 2007: 5). One illustrative industry in this respect is mining, where record commodity prices facilitated the paying down of debt incurred to pursue acquisitions. Industry players saw consolidation as essential to achieving economies of scale and synergies in operations. Today, however, the dominance of resource-based firms in the OFDI of a number of emerging markets brings its own set of challenges (Kalotay, 2010). Natural-resource-based firms account for four-fifths of the foreign assets of the top 25 Russian MNEs, for example (ibid.). Their rapid expansion took place on the back of high commodity prices. While commodity prices have recovered, high levels of debt make for an uncertain future, in which divestiture and further industry consolidation may be the only options available.

Sustainable FDI is another area that presents potential challenges for emerging market MNEs, looking at the importance of FDI along four dimensions: 'economic development, environmental sustainability, social development, good governance' (VCC-WAIPA, 2010: 4) rather than in dollar and employment terms. Just as emerging markets become important players in global FDI markets, the scale against which importance is measured is shifting from quantity to quality (Filippov and Guimón, 2009). This represents a challenge for all MNEs-but the scale of the challenge is perhaps greater for emerging market MNEs. In the case of these MNEs, importance to the domestic economy is still measured in terms of dollars and employment created. In addition, emerging market MNEs are important investors in natural resources, a sector in which until recently the focus has been on short-term contributions measured in dollar terms. The ability of emerging market MNEs to adapt to these new standards is critical to their continued growth and success - and may ultimately have spillover effects in the home country, leading, in the longer term, to a harmonization of standards upwards.

\section{Challenges for home country policies}

Today, while the landscape of home country OFDI policies is very uneven, the vast majority of emerging markets do not provide a supportive environment for the OFDI activities of their firms, placing them at a competitive disadvantage vis-à-vis their developed country counterparts. The principal challenge for home country policy in emerging markets is, within the constraints of limited resources and widespread needs, to create an environment and policy framework that supports 
domestic firms. This framework should enhance their competitiveness, enable them to compete effectively in the global arena and, ultimately, secure the benefits of OFDI for their home countries. Certainly, the substantial rise in outward investment from emerging markets is a relatively new phenomenon, and national policy is not written or rewritten overnight. On the one hand, if emerging market firms are disadvantaged by a continued lack of supportive policies, and thus are hampered in their competition on the world market, they may, in extreme cases, shift their base to another country in order to stay competitive. On the other hand, the scope of government action and policy-making is constrained by economic reality-limited resources, scarce foreign reserves, and potential concerns over the export of capital and jobs.

The lack of a supportive policy framework in many emerging markets ${ }^{7}$ stands in contrast to developed countries, which have built an extensive and comprehensive policy framework over decades, policies that have evolved in tandem with, and complement, their economic situation. The result has been a gradual but persistent shift in home country policy from restricting and controlling OFDI, to permitting it, and finally to promoting OFDI actively, reflecting the recognition that, in a global market, firms must be globally competitive, with OFDI being one source of such competitiveness.

The experience of developed countries in building a policy framework for OFDI offers lessons for policy-makers in emerging markets. In the aftermath of World War II, early restrictions on OFDI focused on capital and foreign exchange controls. Gradually phased out by the early 1980s, these controls were eliminated, finally, as a global capital market became a reality. From restrictions on OFDI, developed countries adapted policies to shape and, ultimately, promote OFDI ${ }^{8}$ (Buckley et al., 2010). However, even with a detailed understanding of the policies implemented in developed countries, challenges remain for emerging markets. While the lack of a clear policy framework leaves domestic firms at a competitive disadvantage, changing the situation is not without its own challenges, given the lack of domestic experience and competence in this area, the risks of regulatory capture, and the absence of a significant social safety net (ibid.).

Coming through the crisis with their relative position in the global economy strengthened has done little to reduce the policy dilemma facing emerging markets. The need for firms to acquire a portfolio of locational assets in order to retain and maximize their competitiveness in a global setting must be balanced against the broad macroeconomic interests of home country needs. Concerns over the export of jobs are as 
relevant in emerging markets as in developed economies (Broadman, 2010). Where national champions or state-owned enterprises (SOEs) from emerging markets undertake FDI, this poses potential political challenges for the home country as much as for the host country. Whilst a relatively small share of total OFDI in most emerging markets, as SOEs move abroad and 'grow up,' they may well seek greater independence in determining their own economic future, free from political constraints (ibid.). Furthermore, critics argue that SOEs crowd out more efficient private companies in markets for financial and human capital (The Economist, 2012: 11). How do home country policy-makers retain control, without hindering the competitiveness of their SOE-MNE? This question remains unanswered; but to hope that as they mature and expand, SOEs will simply throw of their political shackles is unrealistic.

Information on the experiences of developed countries and the different policy options available is useful for emerging markets, but how applicable is it? Furthermore, even with this information, the challenge of sequencing shifts in policy remains. The fact that emerging market MNEs may be 'born global,' or may skip stages of development and internationalization does nothing to lessen the complexity of the policy makers' task (De Beule and Van Den Bulcke, 2010). Rapid globalization and the early internationalization of emerging market MNEs render redundant some of the policy lessons from developed countries. It is more likely that emerging markets will instead combine elements of policy from different stages of development-the selective promotion of OFDI, for example, with retaining elements of control (ibid.).

China is an example of how one particularly important emerging market has addressed the challenges for home country policy and, in particular, the shift from OFDI restriction to promotion. China's OFDI policy evolved in three phases from 1984 to 2008 (Xue and Han, 2010). Adopted largely out of economic necessity in 1984, early policy involved strict controls on OFDI. By 1991, the domestic policy environment had liberalized gradually, and OFDI's role in economic growth was endorsed. From 1991, OFDI policy focused on large SOEs until, in 2000 , funds were established to encourage the internationalization of small and medium-sized firms. The year 2000 also saw the unveiling of China's 'Going Global' policy and the differentiation of OFDI policies into policies of regulation, guidance and support (ibid.). China offers a particularly interesting example: It embraced 'Open-Door' policies only three decades ago but, in a relatively short period, OFDI flows have grown considerably, from only US\$44 million in 1982 to US\$68 billion in 2010 (UNCTADSTAT). Furthermore, the continued and prominent role of SOEs in the Chinese economy and the country's OFDI allows 
the government a degree of direct influence, impossible for most other national policy-makers.

\section{Challenges for host country policies}

In spite of the global economic turmoil, the investment climate for FDI remains overwhelmingly welcoming, and virtually all countries seek to attract inward investment (Figure 2.9). While a certain number of restrictive and adverse measures have been introduced even before the onset of the global crisis, they should be considered in the context of an investment environment that is already largely open. Furthermore, the vast majority of the regulatory measures introduced were limited to specific sectors, including land ownership and investment in natural resources (Economou and Sauvant, 2012), particularly sensitive sectors even in the best of economic times. The OECD's FDI Restrictiveness Index for 2010, measuring the restrictiveness of FDI policies across 48 countries (Figure 2.8) shows that on a scale from 0 (open) to 1 (closed)

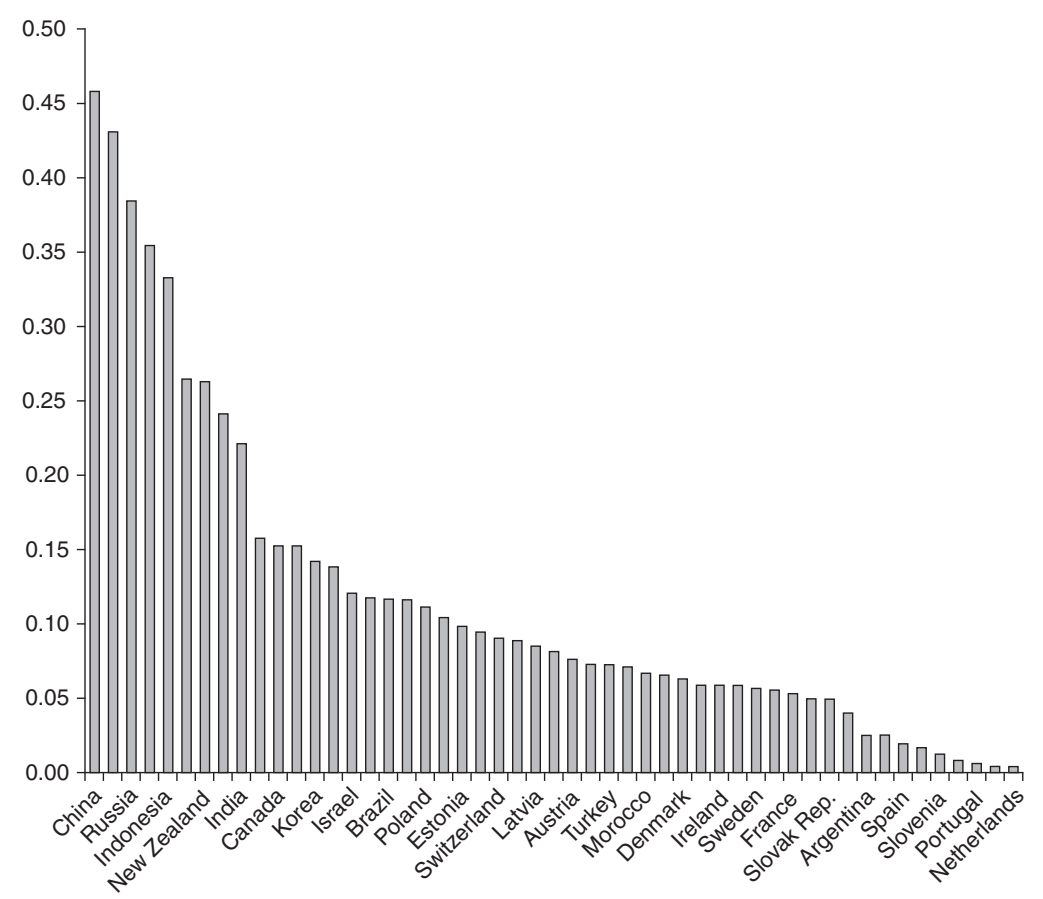

Figure 2.8 OECD's FDI Restrictiveness Index, 2010 Source: Authors, based on OECD (2010). 


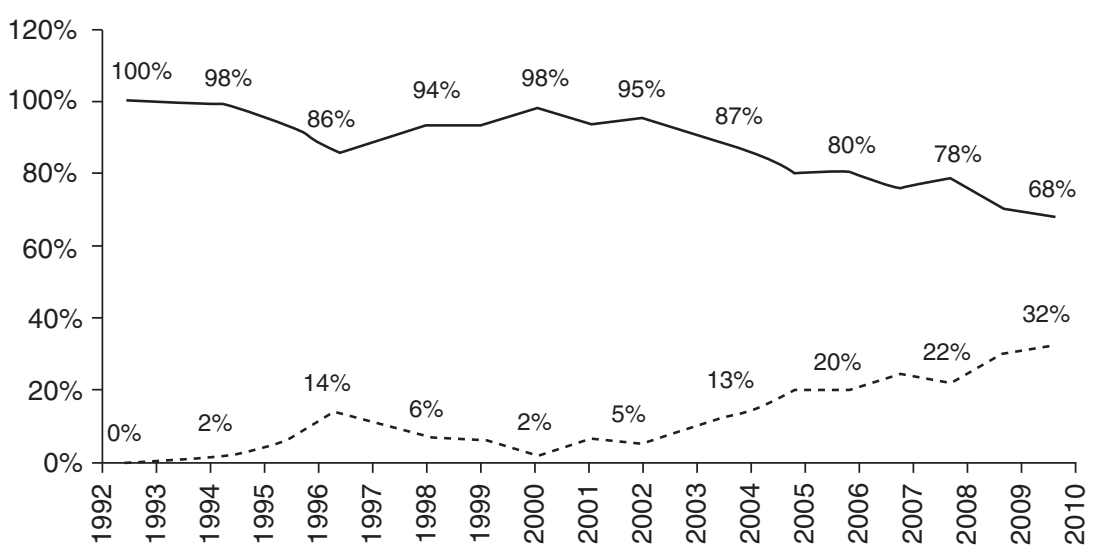

- Liberalization/promotion -.--Regulations/restrictions

Figure 2.9 National regulatory measures, 1992-2010 (\%)

all major economies are rated below 0.46 , and most are rated below 0.15 (OECD, 2010).

Yet, a distinct trend toward a more restrictive investment climate has emerged over the past decade (Figures 2.9 and 2.10) and, in 2010, onethird of all national regulatory measures imposed greater regulation or restrictions on FDI. ${ }^{9}$

In a regulatory environment that has become more restrictive, the rise of outward investment from emerging markets presents its own set of challenges for host country policies, particularly for developed host countries. As noted above, investment by emerging market MNEs in developed economies generally takes the form of acquisitions, often considered less attractive by the host country because of the limited contribution to increased economic output. That the firms being acquired may be deemed part of a 'strategic sector,' raises further concerns over national security. When the acquiring firm is a state-owned enterprise or a sovereign wealth fund, this only amplifies host country concerns. In the US, the share of inward investment notices that progressed to investigations rose from 15 per cent in 2008 to 38 per cent in both 2009 and 2010 (Table 2.2) (Committee on Foreign Investment in the United States, 2011: 3).

The rapid rise in OFDI from China in the past decade and the dominant role played by SOEs in this outward investment represents a particular challenge to host country policy for the US (Sauvant, 2010a,b). 


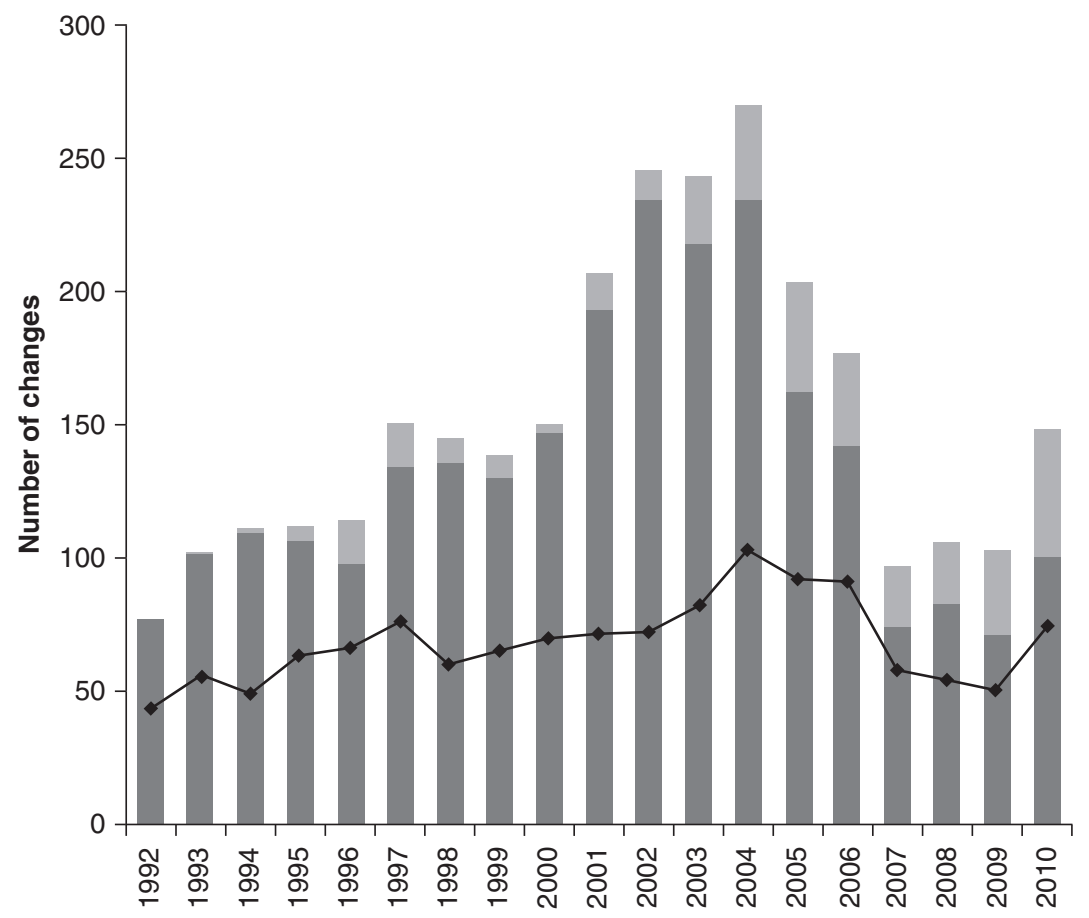

Liberalization/promotion - Regulations/restrictions

$\rightarrow$ Number of countries that introduced changes

Figure 2.10 National regulatory measures, 1992-2010

Source: The authors, based on UNCTAD 2008 (13) and UNCTAD (2011) (94).

Table 2.2 CFIUS: Covered transactions, withdrawals, and presidential decisions, 2008-2010

\begin{tabular}{lrllll}
\hline Year & $\begin{array}{l}\text { Number of } \\
\text { Notices }\end{array}$ & $\begin{array}{l}\text { Notices } \\
\text { Withdrawn } \\
\text { During } \\
\text { Review }\end{array}$ & $\begin{array}{l}\text { Number of } \\
\text { Investigations }\end{array}$ & $\begin{array}{l}\text { Notices } \\
\text { Withdrawn } \\
\text { During } \\
\text { Investigation }\end{array}$ & $\begin{array}{l}\text { Presidential } \\
\text { Decisions }\end{array}$ \\
\hline 2008 & 155 & 18 & 23 & 5 & 0 \\
2009 & 65 & 5 & 25 & 2 & 0 \\
2010 & 93 & 6 & 35 & 6 & 0 \\
Total & 313 & 29 & 83 & 13 & 0 \\
\hline
\end{tabular}

Source: Based on the Committee on Foreign Investment in the United States, Annual Report to Congress (2011: 3). 
By the end of 2010, China had invested almost US\$298 billion abroad, a near ten-fold increase since 20000 (UNCTADSTAT). China is the US government's largest creditor: It holds US\$1.6 trillion of US securities and foreign exchange reserves of US\$3.2 trillion (Morrison and Labonte, 2011: i). The fact that the vehicle of choice for most of this OFDI has been mergers and acquisitions only exacerbates tensions. Policy in the US has become more cautious in recent years, especially with regard to Chinese firms. National security concerns play a more important role in shaping this policy, fed by fears that Chinese investment decisions are driven as much (if not more) by strategic and political motivations rather than by economic motivations. This situation is not completely new, however: Japanese investment once stirred up similar fears, which were successfully allayed when Japanese firms worked closely with the different stakeholders in order to become 'insiders' (ibid., Milhaupt, 2010).

Host country apprehension-founded or not-that certain acquisitions are driven by political rather than commercial objectives will do nothing to reduce restrictions on FDI. Unchecked, this could evolve into FDI protectionism, inflicting damage on the recovery, continued integration, and smooth functioning of the global economy. Protectionism on the part of developed countries, traditionally the main proponents of liberalization, in response to the emergence of new players would border on hypocrisy, and would deprive host (developed) economies of the widely recognized benefits of FDI. Restricting the access of these new players to developed markets would deny their firms vital access to new skills, technologies, and markets, preventing them from building the portfolio of locational assets so essential to their global competitiveness. Ultimately, opportunities for both growth and development, for the firm, home and host economy, would be lost.

\section{The path ahead}

Two decades ago, outward investment from emerging markets accounted for less than 8 per cent of the world's outward investment stock (UNCTADSTAT). The Soviet Union had only recently reintroduced the right of private ownership in an attempt to stimulate its economy. Fifteen years ago, the Asian financial crisis devastated economies across the region and beyond. Today, as global players from emerging markets move toward the center of the world stage, the world is in the grip of the worst economic crisis since the 1930s, a crisis that broke over four years ago and that shows little sign of ending in a number of countries. Looking ahead, what are the main challenges facing FDI and the main actors 
in this process? Will the current economic downturn require them simply to ride out this crisis, with normal business resuming as soon as possible? Alternatively, will the combination of the rise of global players from emerging markets and the global crisis require the rules of FDI to be rewritten?

Perhaps the single most important challenge that emerging market MNEs face relates to their ability to address the heightened levels of political risks resulting from the ongoing global crisis. The relative youth of many emerging market MNEs serves to increase the scale of the challenge. Broadly defined as the probability of disruption of the operations of companies by political forces and events' (MIGA, 2011: 21), until recently, the challenges presented by political risk have been viewed largely in the context of MNEs from developed countries investing in emerging markets. The global crisis has shattered this assumption.

It is important to recognize that, having developed in riskier political and economic environments, emerging market MNEs' notions of risk can be very different from those of developed countries' MNEs. Generally, the greater the levels of political risk in the home country, the greater the tolerance for risk that MNEs develop (MIGA, 2010). Location, sector, size of investment, and home country environment and earlier experience with outward investment all shape their perception of political risk (ibid.). Interestingly, in terms of entry mode, while greenfield investments are considered economically more desirable and less politically risky in developed countries, emerging market MNEs consider them more risky in other emerging markets where 'the presence of a domestic partner tends to reduce risk perceptions' (MIGA, 2010: 228). Fortunately, governments-alone or in conjunction with the private sector-have the ability to minimize the impact of political risk on investment decisions through the provision of insurance, a policy tool that should become an increasingly important element of home country policy in emerging markets.

However, since the onset of the global crisis, emerging market MNEs are most concerned by changes in the regulatory framework (Figure 2.11) and more concerned about such changes to the investment climate than they are about the state of the global economy and access to financing (MIGA, 2011). In particular, it is 'the instability of the regulatory regime... rather than the regime itself' that concerns investors (MIGA, 2011: 22). The dramatic growth and strong performance of emerging markets and their MNEs mitigated the scale of the global downturn. The recovery of the global economy is patchy and remains 


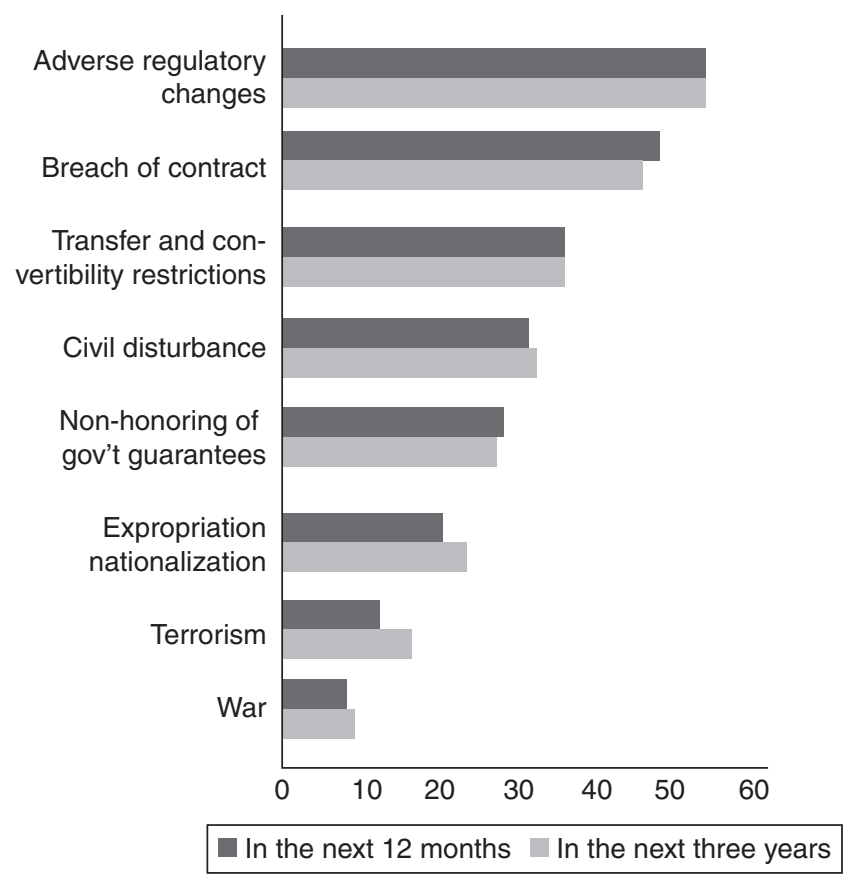

Figure 2.11 Types of political risk of most concern to investors in developing countries (\% respondents)

Source: MIGA-EIU Political Risk Survey, reproduced in MIGA (2011) World Investment and Political Risk Report, 20.

fragile. It is vital that efforts are made to keep the global economy open to outward investments from emerging markets.

The financial crisis and subsequent government rescue programs have increased previously high public debt to unsustainable levels in several developed economies-in excess of 100 per cent of gross domestic product (GDP) in Ireland, Portugal, Greece, and Italy (Eurostat, 2012). Not since the 1930s has a Western European country defaulted on its debt, but there is real concern today that, orderly or disorderly, Greece cannot avoid a sovereign default. Greece's creditors are at immediate risk, and investors are wary of an economy that is in its fifth year of contraction. The greatest risk, however, is that this sovereign debt crisis will spread beyond Greece to other highly in debt Eurozone economies: Ireland, Portugal, Spain, and (of most concern given the size of its economy) Italy. The potentially disastrous consequences for the European 
economy should fears of contagion become reality, make this one of the most pressing risks of the day. Moreover, the EU is a key pillar of the global economy, a vital source of, and destination for FDI, with the Euro a global reserve currency that accounts for close to 27 per cent of the world's currency reserves (The Economist, 2011). Whatever happens within the Eurozone and the European Union, therefore, will have dramatic implications for the global economy and FDI. Rising levels of civil unrest hinder the economic reform efforts of national governments and raise concerns about the stability and predictability of future policies. The crisis in Greece has laid bare the slow and unwieldy nature of EU policy-making and, more worryingly, the divisions that exist among member nations, exacerbated in these tough economic times. Further uncertainty in this region could well tip the global economy back into recession.

\section{Conclusions}

This chapter has sought to place the rise of emerging market MNEs in context, examining the role of these new global players in global FDI flows, how they have responded to the global crisis, and the challenges inherent in their rise for MNEs themselves as well as for home and host countries. Whatever the tensions and temporary setbacks, the great number of firms undertaking FDI will build an ever more interconnected and integrated international production system.

All this, finally, needs to be seen against one basic fact: Countries do not look at FDI as an end in itself. Rather, it is seen as a tool to advance their development, be it as a home country or host country. As part of that, FDI is a powerful means to help countries in their integration into the world economy. In addition, economic development through integration into the world economy is one of the means by which countries lift themselves out of poverty. Despite the global crisis, much progress has been made in recent years, yet much remains to be done-and the greater the number of firms involved in this process the better it is for all of us.

Finally, efforts to build a multilateral investment framework must be stepped up. The need to address and allay concerns that feed growing economic nationalism and FDI protectionism is not limited to MNEs, home and host country governments: This situation highlights the important role that international organizations must play if the international investment regime is to remain relatively open, transparent, and stable. An international framework, establishing best practices and 
minimum standards, and bringing greater transparency to the now truly international investment regime are to the benefit of all.

\section{Notes}

1. According to UNCTAD terminology, the group of 'developed economies' comprises the 27 Member States of the European Union, plus Australia, Bermuda, Canada, Gibraltar, Iceland, Israel, Japan, New Zealand, Norway, Switzerland, and the US. 'Emerging markets' comprise both 'developing countries' and 'transition economies.' The 'transition economies' group consists of the six countries of Southeast Europe (Albania, Bosnia and Herzegovina, Croatia, The FYR of Macedonia, Montenegro, and Serbia) as well as the twelve countries of the Commonwealth of Independent States (CIS): Armenia, Azerbaijan, Belarus, Georgia, Kazakhstan, Kyrgyzstan, the Republic of Moldova, Russian Federation, Tajikistan, Turkmenistan, Ukraine, and Uzbekistan. All other countries are 'developing countries'.

2. For a full discussion, see Sauvant et al. (2010); Sauvant (2010); Ramamurti and Singh (2009); Ramamurti (2008); Sauvant et al. (2008).

3. See UNCTAD (2011, annex table 25), note ${ }^{\text {a }}$.

4. UNCTAD (2011, annex table 25) Notes states that 'Data should be interpreted with caution. The world total was extrapolated on the basis of data covering 29 countries in 1990 and 54 countries in 2009, or latest year available. They account for 82 and 89 per cent of world outward FDI stock, respectively, in 1990 and in 2009. Only countries for which data for the three main sectors were available were included. The distribution shares of industries of these countries were applied to estimate the world totals of sectors and industries. As a result, the sum of the sectors for each group of economies is different from the totals shown in annex table 2. Approval data were used for India (2005 instead of 2007) and Taiwan Province of China. For 1990, the world total includes the countries of South-East Europe and the CIS although data by sector and industry are not available for that region. Moreover, as major home developing economies were not covered due to lack of data, the respective shares for developing economies were underestimated in that year,') http://www.unctad.org/sections/dite_dir/docs/WIR11_ web\%20tab\%2025.pdf, last visited March 9, 2011).

5. Measured by foreign assets.

6. For a discussion of the rise of Indian MNEs, see Sauvant et al. (2010).

7. The term 'emerging markets,' the grouping together of developing countries and transition economies, risks giving the impression, falsely, of a homogenous group of countries. It should also remind us of the limitations inherent in any attempt to construct one policy framework that fits all emerging markets. The key to successful policy is to ensure that it is appropriate to the stage of development of the national economy.

8. The authors group these measures into seven categories: '(i) the provision of information and technical support, (ii) financial support, (iii) fiscal incentives, (iv) investment insurance and guaranteed, (v) support of national champions, (vi) international investment related concordats and agreements, 
and (vii) official development assistance (ODA) programs' (Buckley et al., 2010: 259).

9. Available data for 2011 (January-September 15), appear to show a slight shift toward a more relaxed investment climate, with almost three-quarters of all the measures adopted liberalizing or promoting FDI, but it is perhaps too soon to draw any definitive conclusions.

\section{References}

Broadman, H.G. (2010). Multinational enterprises from emerging markets: Implications for the North and the South, in K.P. Sauvant, G. McAllister, and W.A. Maschek (Eds) Foreign Direct Investments from Emerging Markets: The Challenges Ahead, New York, NY: Palgrave MacMillan: 325-334.

Buckley, P.J., Clegg, J.L., Cross, A.R., and Voss, H. (2010). What can emerging markets learn from the outward direct investment policies of advanced countries? in K.P. Sauvant, G. McAllister, and W.A. Maschek (Eds) Foreign Direct Investments from Emerging Markets: The Challenges Ahead, New York, NY: Palgrave Macmillan: 243-276.

Clover, C. and Belton, C. (2008). Retreat from Moscow, investors take flight as global fears stoke Russian crisis. The Financial Times, September 17, 2008: 13.

Committee on Foreign Investment in the United States. (2011). Annual Report to Congress, Washington, DC: CFIUS.

Congressional Research Service. (2009). The Global Financial Crisis: Analysis and Policy Implications, July 10, 2009, fpc.state.gov/documents/organization/ 127296.pdf.

De Beule, F. and Van Den Bulcke, D. (2010). The global crisis, foreign direct investment and China, Brussels Institute of Contemporary China Studies, 5(6): $1-31$.

ECLAC. (2009). Foreign Direct Investment in Latin America and the Caribbean: Briefing Paper, Santiago: ECLAC.

Economou, P. and Sauvant, K.P. (2011). From the FDI Triad to multiple FDI poles? Columbia Perspectives 418, New York, NY.: Vale Columbia Center on Sustainable International Investment.

Economou, P. and Sauvant, K.P. (2012). Recent trends and issues in foreign direct investment, 2010, in K.P. Sauvant (Ed.) Yearbook on International Investment Law \& Policy, New York, NY: Oxford University Press: 3-36.

Eurostat. (2012). Eurostat News Release 20/2012. Brussels: Eurostat.

Filippov, S. (2011). Russia's emerging multinational companies amidst the global economic crisis. UNU-MERIT Working Paper Series 2011-003.

Filippov, S. and Guimón, J. (2009). From quantity to quality: Challenges for investment promotion agencies. UNU-MERIT Working Paper Series 2009-057.

IMEMO and VCC. (2011). Investment from Russia Stabilizes After the Global Crisis. Moscow and New York, NY: IMEMO and VCC.

International Monetary Fund. (2010). How Did Emerging Markets Cope in the Crisis? Washington, DC: International Monetary Fund. 
Jaklič, A. and Svetličič, M. (2010). Unknown multinational enterprises: Top MNEs from Slovenia, in K.P. Sauvant, G. McAllister, and W.A. Maschek (Eds) Foreign Direct Investments from Emerging Markets: The Challenges Ahead, New York, NY: Palgrave Macmillan: 197-226.

Jellinek, R. (2009). Russia and the Global Meltdown: Domestic and Foreign Policy Responses to the International Financial Crisis, Carnegie Moscow Center Report, Moscow: Carnegie Moscow Center.

Kalotay, K. (2010). Takeoff and turbulence in the foreign expansion of Russian multinational enterprises, in K.P. Sauvant, G. McAllister, and W.A. Maschek (Eds) Foreign Direct Investments from Emerging Markets: The Challenges Ahead, New York, NY: Palgrave Macmillan: 113-144.

Kumar, N. (2007). Emerging TNCs: Trends, patterns and determinants of outward FDI by Indian enterprises, Transnational Corporations, 16(1): 1-26.

MIGA. (2010). South-south foreign direct investment and political risk insurance: Challenges and opportunities, in K.P. Sauvant, G. McAllister, and W.A. Maschek (Eds) Foreign Direct Investments from Emerging Markets: The Challenges Ahead, New York, NY: Palgrave Macmillan: 227-242.

MIGA. (2011). 2011 World Investment and Political Risk. Washington, DC: MIGA.

Milhaupt, C.J. (2010). Is the U.S. ready for FDI from China? Lessons from Japan's experience in the 1980s, in K.P. Sauvant (Ed.) Investing in the United States: Is the U.S. Ready for FDI from China? Cheltenham: Edward Elgar: 185-208.

Ministry of Finance of the Russian Federation. (2012). Aggregate amount of the reserve fund. Ministry of Finance of the Russian Federation.

Morrison, W.M. and Labonte, M. (2011). China's Holdings of U.S. Securities: Implications for the U.S. Economy, Washington, DC: Congressional Research Service.

Nanto, D.K. (2009). The Global Financial Crisis: Analysis and Policy Implications, Washington, DC: Congressional Research Service.

OECD. (2010). OECD Economic Outlook Volume 2010/2. Paris: OECD.

Panibratov, A. and Kalotay, K. (2009). Russian outward FDI and its policy context. Columbia FDI Profiles, Vale Columbia Center on Sustainable International Investment, No. 1. http://www.vcc.columbia.edu/files/vale/documents/FDI_Profile-_ Russia.pdf, Accessed on February 6, 2012.

Pradhan, J.P. (2011a). Emerging multinationals: A comparison of Chinese and Indian outward foreign direct investment, International Journal of Institutions and Economies, 3(1): 113-148.

Pradhan, J.P. (2011b). Firm performance during global economic slowdown: A view from India, Economics, Management, and Financial Markets, 6(1): 57-81.

Price Waterhouse Coopers. (2007). Mine: Riding the wave.

Ramamurti, R. (2008). What Have We Learned About Emerging Market MNEs? Cambridge: Cambridge University Press.

Ramamurti, R. and Singh, J.V. (Eds) (2009). Emerging Multinationals in Emerging Markets. Cambridge: Cambridge University Press.

Resende, P., Almeida, A., and Ramsey, J. (2010). The transnationalization of Brazilian companies, in K.P. Saivant, G. McAllister, and W.A. Maschek (Eds) Foreign Direct Investments from Emerging Markets: The Challenges Ahead, New York, NY: Palgrave Macmillan: 97-112. 
Sauvant, K.P. (Ed.) (2010a). Investing in the United States: Is the U.S. Ready for FDI from China? Cheltenham: Edward Elgar.

Sauvant, K.P. (2010b). Is the United States ready for foreign direct investment from emerging markets? The case of China, in K.P. Sauvant, G. McAllister, and W.A. Maschek (Eds) Foreign Direct Investments from Emerging Markets: The Challenges Ahead, New York, NY: Palgrave Macmillan: 359-380.

Sauvant, K.P., Maschek, W.A., and McAllister, G. (2010). Foreign direct investment by emerging market multinational enterprises, the impact of the financial crisis and recession, and challenges ahead, in K.P. Saivant, G. McAllister, and W.A. Maschek (Eds) Foreign Direct Investments from Emerging Markets: The Challenges Ahead, New York, NY: Palgrave Macmillan: 3-30.

Sauvant, K.P., McAllister, G., and Maschek, W.A. (Eds) (2010). Foreign Direct Investments from Emerging Markets: The Challenges Ahead, New York, NY: Palgrave Macmillan.

Sauvant, K.P., Mendoza, K., and Ince, I. (Eds) (2008). The Rise of Transnational Corporations from Emerging Markets: Threat or Opportunity? Cheltenham: Edward Elgar.

Sauvant, K.P., Pradhan, J.P., Chatterjee, A., and Harley, B. (Eds) (2010). The Rise of Indian Multinationals, New York, NY: Palgrave Macmillan.

The Economist. (2011). Climbing greenback mountain, September 24.

The Economist. (2012). The rise of state capitalism, January 21.

The People's Bank of China. (2008). Gold and foreign exchange reserves.

The People's Bank of China. (2010). Gold and foreign exchange reserves.

The World Bank. (2011). Global Development Horizons: Multipolarity - The New Global Economy, Washington, DC: The World Bank.

Trading Economics. (2012). Brazil stock market.

UNCTAD. (2005). World Investment Report 2005: Transnational Corporations and the Internationalization of R\&D. New York, NY; Geneva: UNCTAD.

UNCTAD. (2011a). World Investment Report 2011, Annex Table 10. Value of CrossBorder M\&As by Region/Economy of Purchaser, 1990-May 2011. New York, NY; Geneva: UNCTAD.

UNCTAD. (2011b). World Investment Report 2011: Non-Equity Modes of International Production and Development, New York, NY; Geneva: UNCTAD.

UNCTAD. (2011c). Global Investment Trends Monitor No. 5.

UNCTAD. (2011d). Global Investment Trends Monitor No. 6.

UNCTAD. (2011e). Global Investment Trends Monitor No. 7.

UNCTAD. (2012a). Global Investment Trends Monitor No. 8.

UNCTAD. (2012b). Inward and outward foreign direct investment flows, annual, 1970-2010, UNCTADSTAT.

UNCTAD (2012c). Real GDP growth rates, total and per capita, annual, 19702010, UNCTADSTAT. http://unctadstat.unctad.org/TableViewer/tableView. aspx?ReportId=109, Accessed on February 6, 2012.

Vale Columbia Center on Sustainable International Investment and World Association of Investment Promotion Agencies. (2010). Investment Promotion Agencies and Sustainable FDI: Moving Toward the Fourth Generation of Investment Promotion. New York, NY: VCC-WAIPA.

Wisniewska, I., Dubas, A., and Rogova, J. (2010). Russia in Crisis: Year One, Warsaw: Centre for Eastern Studies. 
The World Bank. (2012). World Development Indicators, March, New York, NY: The World Bank, World Development Indicators.

Xue, Q. and Han, B. (2010). The role of government policies in promoting outward foreign direct investment from emerging markets: China's experience, in K.P. Sauvant, G. McAllister, and W.A. Maschek (Eds) Foreign Direct Investments from Emerging Markets: The Challenges Ahead, New York, NY: Palgrave Macmillan: 305-324. 


\section{Index}

The names of all authors are not listed in the index; readers wanting the names of all authors and titles of all sources are advised to refer to the references after each chapter.

Abramczuk, C., 124, 127, 129

ACP (Asseco Poland), 96

acquisition activity, 52, 74

acquisitions, $6,8,21,28,30-2,36$,

$38,47-69,72-5,79-82,96-7$, $149,179,186-7,192-4,200,205$, 207-8, 210, 212, 217, 221, $229-30,233,236,243,245,276$, 278,281

strategic, 13, 184, 219

vertical, 57-8, 61, 63-4, 66

advanced countries, 47-8, 53, 56, 63, $66,67,73,74,143$

Afonso, A., 87

Africa, 5, 95, 156, 158, 163-4, 193, $198,226,245,347$

Agromashholding, 196

Aguilera, R., 158-60, 170-1, 173

Aharoni, Y., 316

Ahokangas, P., 336

Akhter, S., 294

Alamdari, F., 306

Albania, 42, 96, 277

Aldrich, H., 121

Alfa-Bank, 195

Algeria, 226

Aliber, R., 141

Allen, R., 182

Almaz Capital, 197

Alpina, 273

Altzinger, W., 263, 288

Alvarez, R., 183

Ambos, B., 248

Amburgey, T., 121, 158

American companies, 347

Andersen, O., 315

Andreff, W., 84, 181

Apigian, C., 125
Arbat Prestizh, 200

Arcelor Mittal, 323

Arenius, P., 116-17

Argentina, 4-5, 35, 184, 235

Armenia, 42, 195

Arratibel, O., 85, 99

ASEE (Asseco South Eastern Europe), 96

Ashby, W., 104, 129

Asia, 5, 23, 87, 95-6, 100, 108, 154, $164,182,193,198,245,282$, 299, 301, 307, 313, 321, 326-7, 330,333

Asian countries, 109, 162, 165

Asian crisis, 1, 157, 183, 218

Asian economic crisis, 81, 221, 313

Asian financial crisis, 38, 260

Asian firms, 94, 143

Aspelund, A., 337

assets, 25, 60, 64, 68, 73, 95, 109, 137, 141, 181-2, 188, 194, 199, 202, 205-6, 217, 223, 236, 263, 281, $285,305,308,314$

acquisition of, 215-16

financial, 1

fixed, 188

managerial, 64

physical, 61

asset specificity, 57

Athukorala, P., 183

Aulakh, P., 116, 318

Australia, 42, 95, 132-3, 152, 156, 164, 167, 193, 311, 352, 364

Australian Manufacturing Council, 338

Austria, 35, 54, 86, 91-2, 96, 167, 174, 195, 200, 202-4, 270, 278, 284 
automotive industry, $94,97,188,208$, 222-4, 226-7, 229-30, 232, 237, 272,278

automotive manufacturers, 223, 235-6 average OFDI flows, 15

average R\&D spending, 55

AvtoVAZ, 191, 192, 196, 202, 208

Aykut, D., 261, 288

Azerbaijan, 42, 195

Baek, H., 141, 151

Bahrain, 3

BAIC (Beijing Automotive Industry Corporation), 226, 233-4, 236

Baltic countries, 165, 302

Baltika, 195, 200

Bangladesh, 167, 226

Bank of China, 28, 45, 236

banking sector, 97-8, 187, 263

bankruptcy, 93, 269, 273-4, 299, 305

Bank of Slovenia, 270

Bardhan, P., 230, 238

Barkema, H., 155, 158-60, 171-3

Barnard, H., 48-9, 51-2, 54, 56, 143

Barney, J., 241

Barrett, N., 118, 122-3

Barrington, L., 266, 284

Bartlett, C., 113, 120

BCG, 67

Beamish, P., 113, 115, 120, 294, 335,340

Beaver, G., 292-3, 306

Beijing, 175, 229, 234, 321

Beijing Geely Kaixuan International Investment, 236

Belarus, 42, 194-5, 204, 302, 324-5, 346

Belgium, 54, 86, 88, 92, 196, 203

Bell, J., 119, 132, 174, 336-40, 362

Benito, G., 159, 173, 181, 294, 335,340

Bennett, R., 115, 118

Benson, J., 110

Benson-Rea, M., 335

Berlin Wall, 84

Berry, M., 104, 114, 120, 122-3

Bertoncelj, M., 278, 284, 286-7

Bertoni, F., 8, 47

Beugelsdijk, S., 256
Billington, N., 142, 247

Birley, S., 338

Blaine, M., 112

Blomkvist, K., 9, 154

Blonigen, B., 141-2, 149

Boddewyn, J., 315

Bolivia, 174

Borås Wäfveri AB, 299

Borghoff, T., 8, 102, 104, 122

born global firms, 12, 109, 115, 334-41, 349, 361-2

Born Global Model, 338, 349, 359

born globals, 34, 109, 114, 117, 133, 334-6, 338, 340, 358-9, 362

Bosnia-Herzegovina, 42, 85, 96, 203

Boudier-Bensebaa, F., 84

Bower, J., 112

Bradley, S., 111

brand, 57, 228, 236, 238, 241, 243, $324-5$

awareness, 65

recognition, 66

Braun, M., 293, 305, 312

Brazil, 4, 8, 16, 24, 30-1, 35, 49-50, $52-3,56,61,67-70,82,84,97$, $129,142,177,179,181-2,184$, 198, 226, 274, 278, 287, 296, 340,353

Brennan, L., 9, 138

Brewer, T., 159

BRIC acquisitions, 8, 50-5, 57, 61, 68, 74

in Western Europe, 50, 69

BRIC countries, 5, 56, 74-5, 217, 266, 271,282

BRIC economies, 5-8, 29, 184

BRIC firms, 49, 65, 67, 75

BRICs, 47, 49-53, 55, 58, 60, 65, 67-9, $72,74-5,82,177,181,271$

Bridgewater, S., 104, 117

British Virgin Islands, 194, 200, 300

Brock, B., 104, 114, 120, 122-3

Brunner, S., 158

Brynjolfsson, E., 112

Buckley, P., 33, 43, 57, 61, 84, 137, $141,154,156-7,160,162-3,170$, 172-4, 181, 240-2, 244, 247-9, 294, 315 
budget deficits, 86

Bulatov, A., 181-2

Bulgaria, 85, 87-8, 92, 96, 205, 301

Burger, A., 267-8

business activities, 19-20, 79, 183,320

business environment, 216, 308

business groups, 81,152

business models, 112-13, 124, 260, 266

business networks, 128, 336

Buttriss, G., 119

Calderon, C., 260

Calof, J., 294, 335, 340

Cambodia, 198

Campbell-Hunt, C., 339

Canada, 35, 42, 49, 54, 149, 163, 194, 197, 204, 206, 296, 343-4, 346, 349,351

Cantwell, 48, 51-2, 54, 56, 111, 120 , 122

capabilities, 48, 113, 123, 143, 225-6, $230,236-7,248,280,315$

catch-up, 320

downstream, 63

dynamic, 134, 294, 312-13

technological, 143-4, 150

capital

flight, 157, 187

flows, 26-7

intensity, 222

investment, 2, 21

social, 283

state-owned, 216

capital markets, 142, 272

domestic, 30

international, 30

Capron, L., 49, 57, 241

Cardone-Riportella, C., 317

Carman, J., 316

Casson, M., 57, 156, 315

Castellacci, F., 315

Castells, M., 104

Cavusgil, S., 115, 120, 316, 337-9, 349

Cayman Islands, 164, 194, 200

Cazorla-Papis, I., 317
CEE (Central and Eastern Europe), 8, 83-4, 86, 88, 90, 92, 94-6, 98-100, 263, 273, 307

countries, 85, 87-90, 92-3, 95, 97-9

firms, 84, 95

region, 84, 87, 90, 98

Central Asia, 156

Central Bank of Chile, 218

Chadwick, M., 314

Chakrabarti, A., 144, 244, 246-7

champions

hidden, 262, 267-8, 283, 285, 290

national, 34, 42, 223, 227

cheetahs, 11, 274-5, 278, 280-1, 285

Chetty, S., 295, 339

Child, 116, 155-6, 181, 320

Chile, 226

China, 2-6, 8-9, 24, 27-8, 34-6, 38, 43-5, 49-54, 67-70, 81-2, 107-8, 154-8, 160-5, 167-8, 170-4, 177-9, 181-2, 222, 224, 226-9, 231-2, 234, 236-8, 271-2, 285, 287, 296-7, 321-2, 343, 346-7

Daily, 236, 238

Ministry of Foreign Affairs, 164, 175 OFDI, 155-6

OFDI policy, 34

OFDI stock, 28

Statistical Yearbook, 162-4, 177

Chinese, 8, 10, 52, 61, 74, 81, 122 , $152,154,157,184,222-32,234-8$, $285,289,335,342-4,346,355$

acquisitions, 56-7, 60

authorities, 28, 222, 224, 227-9, 236

automaker Geely, 179

automobile groups, 225

brands, 238

business networks, 175

Communist Party, 223

companies, 69, 72, 154, 160, 228, 232, 320

consumers, 229, 232, 236

Diaspora, 176

economy, 28, 34, 157, 223, 230

enterprises, 227, 232-3

firms, 9, 28, 38, 53, 56, 60, 73, 82, $85,95,156-8,160,168,171-3$, 


\section{PROOF}

Index 369

$175,177-8,181,218,222-3$, $225,230,233,236-8,332,341$ government, 10, 53, 155-7, 164, $174,223,231,285$

manufacturers, 223, 225, 235, 238, 346

market, 224, 229, 238, 349

minorities, 158, 162, 173

minority groups, $155,158,172$

OFDI, 9, 53, 79, 154-6, 158, 160-2, $164-5,168,170-4,244$

partners, 227, 231-2, 286

choice, $38,72,74,117,142,151$,

242-4, 316-17, 329, 331

Choudry, Y., 294, 311

Chowdhury, A., 149

Cirman, A., 264

CIS (Commonwealth of Independent States), 42, 100, 182, 193-5, 200, 217-18, 326-8, 330

Clausen, L., 172

co-evolutionary approach, 365

Colombia, 167-8, 174, 198, 296

Commerzbank, 209

commitment, 183, 334, 336, 339, 353

commodity prices, 24, 26, 32, 217

communication technologies, 9, 102

companies

foreign controlled, 264

gas, 204-5

high-tech, 318, 328, 330

independent, 238

international, 321, 326

local, 256, 323, 325, 327

parent, 24-5, 30, 209, 256, 299, 309

competence

core, 283

new, 266

organizational, 67

technological, 130

competition, 33, 47, 91, 130, 319, $322,326,328$

price, 228

competitive

advantages, 48, 75, 83, 91, 93, 102,

111, 134, 192, 258, 266, 314,

318,329

positions, $216-17$ competitiveness, 33-4, 48, 66, 91, 141, $173,287,318$

competitors, 62, 73, 265, 268, 275, 280-1, 302, 305, 318, 329, 336

complementary

products, $60,66,306$

resources, 73

complexity, 34, 102, 104, 112, 121, $123,238,256$

Concern Traktornye Zavody, 196

conglomerate, 8, 57-8, 64, 71, 73, 75 acquisitions, 49, 58, 64-5, 67, 75

firms, 65

investments, 8, 67

mergers, 82

transactions, 73

consolidation, 32, 228, 230, 274, 277-8, 280

constraints, 32, 103, 228, 317

institutional, 73

political, 34

security, 232

construction sector, 286

consumers, 208, 229, 284, 316

consumption

domestic, 224

energy, 226

household, 237

private, 237

context

emerging economy, 10

global, 99, 104-5, 119, 220

institutional, 81

international, 103

convergence conditions, 86

co-operation, 104, 111, 238, 271, 297, 301, 304, 307, 309, 343, 347, 357

bilateral, 271

international, 339

international economic, 269, 282, 288

coopetition, 319-20

corporate

governance, 212

strategy, 134

corporations

government-owned, 211

state-owned trading, 157

Cosmote, 323 
cost advantages, 357

countries

developed, 3-4, 8, 21, 25, 33-4, $38-9,48-50,52-3,55-9,63$, 65-6, 68-9, 74, 89, 91, 94, 96, 143, 158, 173, 224-5, 233, 237, $240,243,256,261,320$

developing, 6, 40, 42, 51, 53, 56, 91, $100,138,144,152,155-6,158$, 173, 225-6, 234-5, 243, 247, $261,269,271,317,319,333$

emerging, 47-9, 230, 237, 355

high-income, 65

industrial, 261

least developed, 99, 158, 175, 332

less developed, 99

small, 108

Coviello, N., 116, 339

Crane, K., 181

Crick, D., 294

crisis

adjustments, 184-5

banking, 264

corporate, 312

credit, 28

domestic, 274

exit, 277

global, 1-4, 6-13, 14-15, 17, 20, $23-5,27-9,35,39,41,43,83-5$, 92, 95-8, 102, 179-80, 184, $186,188,192,194,199-200$, 204, 206, 208-10, 215-16, 218-20, 254-6, 259-60, 288-90

management, 267

period, 4, 11-12, 192, 194, 204

prevention, 292

CRM (customer relationship management), 110-12, 114, 128

Croatia, 42, 85, 96, 278

cross-border acquisitions, 48, 51, 62

alliance modes, 99

mergers, 6, 81, 186, 243

CSA (Country Specific Advantage), 74, 315, 328-9

Cuadros, A., 144
Cuervo-Cazurra, A., 66, 84, 158, 294, 320

cultural

differences, 9, 154-5, 160, 165, 171-3, 177

distance, 9, 154-6, 158-62, 164-5, $168,170-8,317$

proximity, 172, 245, 253-4

culture, 154-5, 159, 172-3, 176, 316

dimensions, 161, 171-2

distance, 168,170

national, 158, 165, 168, 170

currencies

foreign, 29, 92-3, 141, 204

global reserve, 41

local, 93

currency reserves, 26

customer(s)

behavior, 293

indigenous, 316

local, 12

segments, 310

Cyprus, 86, 88, 92, 174, 193-4, 196, 300

Cyrillic alphabet, 325

Czech Republic, 85, 88, 91-3, 96, 206, $245,270,285,322$

Daimler AG, 208, 238

Daimler-Chrysler, 233

Dana, L., 113

Danford, G., 117, 127

debt

denominated, 29

finance, 30

level of, 87, 92-3, 97

servicing, 87

sovereign, 185

transactions, 174

decision, 20, 30, 75, 117, 134, 138,

$159,183,209,211,227,267,273$,

$287,317,329,353,355,361$

decentralized, 266

managerial, 281

market selection, 119

political, 188

technology adoption, 132

decision-making processes, 117, 121

strategic, 103 


\section{PROOF}

Index 371

de-internationalization, 12, 294, 335, $340,351-2,357,359$

delivery times, 299

Deng, P., 154, 156

Deng Xiaoping, 156-7

Denmark, 35, 54, 86, 88, 167, 196

depreciation premiums, 188

Derbes Breweries, 200

deregulation, 18, 27, 29, 47

de Ruyter, J., 316

Desai, P., 139, 183

determinants, 44, 81, 83, 119, 149 , $152-3,155,181,246,315,332$, 340

of direct foreign investment, 152 of success, 133

devaluation, 205, 278

developed

economies, 1, 3-4, 6, 8, 15, 18-19, 21-3, 27, 29, 34, 36, 40, 42, $48-9,51,53,56,74,93-4,151$, $237,248,320,326$

markets, 38, 67, 81, 156, 226, 325

development, 9-11, 31, 34, 38, 41-2, $45,67,79,82,99-100,105-6$, 110-11, 114, 116, 118, 123-4, $137,139,150,154-7,177,187$, $211,220,223,227,231-2,273-4$, 287-8, 320-4

institutional, 178

social, 32

strategies, 280

sustainable, 355

technological, 314

Didier, 260

differentiation strategy, 337, 351

dinosaurs, 11, 274, 277, 280-1

discontinuous change, 118

disposable income, 224

distance, 171, 175-8, 244, 247

geographic, 248-9, 252-3

distribution, 52, 54, 68, 162, 177, 232, $285,329,337,351$

networks, 63, 73, 321

diversification, 94, 96, 275, 278, 280, 341, 352-3

corporate, 130

geographic, 75

diversified asset base, 208
Dnepropetrovsk, 203

Dneprovagonremstroy, 203

Dnevnik, 291

Doane, D., 249, 253, 257

Doh, J., 154, 164, 172

Domadenik, P., 276, 284-6

domestic

demand, 5, 24, 86, 187, 206, 264

firms, 33, 139, 150, 183, 221, 241, $260,272,291,351$

market, 66, 75, 188, 192, 223-5, $237,243,264,267,287,315$, $317,328,340,344,346-7,349$, $353,355,358-9,361$

market characteristics, 314, 319

partners, 39, 357, 359

Donetsk, 202

Donovan, K., 117

Dooley, K., 295, 305

Dow Chemicals, 205

Dow, D., 155, 158-9, 205

Doz, Y., 113

Drogendijk, R., 9, 154, 158, 159, 160, $161,162,172$

DST (Digital Sky Technologies), 211

Dubrovski, D., 292-3, 312

Dunning, J., 48, 54, 57, 61-2, 67, 79, 90, 97, 110, 117, 120, 137-9, 143, 148-9, 181-2, 241-4, 246-8, 314-15

Düsseldorf, 346

Duysters, G., 65

Dyer, W., 341

East Africa, 161

East Asia, 85, 97-8

Eastern Europe, 8, 84, 100, 219, 273, $278,322,325,346$

Eastern European, 99, 261, 320

countries, 83, 86, 90, 94, 98

e-business, 117-19, 130, 132 development, 131

Eclectic Paradigm, 130, 135, 242, 332

e-commerce, 103-4, 110, 114, 131, 136

corporations (ECCs), 135

metrics, 136 
economic

activities, 26, 52, 130, 136, 163, 179, 186

architecture, 283

conditions, 94, 149, 216

crisis, 17, 31, 90, 93-4, 180, 182-3, $185,216,219-20,260,263$, $269,276,289,292-5,297,302$, 304-6, 309-10, 312

development, 32, 41, 83, 106, $138-9,148,150,152-3$

disparities, 84

downturn, 179, 205

environment, 39, 305, 309-10

geography, 122, 133

growth, 17, 34, 87, 89, 139,

$144,149,151,185-6$,

237, 244

growth rate, 88-9, 255

impacts, 236

nationalism, 41

performance, 2-4, 82, 185-6, 258

policy, 3, 87, 148, 152, 294

recession, 2, 184, 293, 295, 311-12

stagnation, 18

economies

advanced, 2-3, 9, 48-9, 74-5, 181

developing, 15, 42, 49, 79, 99, 222, 318,320

domestic, 26-9, 32, 94

global, 18, 23, 26, 33, 38-41, 45, 80, $99,182,215,218-19,240,282$, 317

economies of scale, $32,57,119,142$, 223, 242-3, 286

Eden, L., 48

education, $67,133,143,250,287$, 311,347

efficiency, 102, 122, 194, 205, 243, 253, 272, 274-5, 292

Egelhoff, W., 113, 121

Ein-Dor, P., 115

Eisenhardt, K., 107, 112, 123, 126, 295,318

Ekeledo, I., 316

electronic book series Analize CMO, 288

Elenkov, L., 319

Elia, S., 8, 47
Ellis, P., 339

embeddedness, 134, 259, 363

local, 183

emerging

economies, 2-8, 10, 12-13, 31, 47, 80-5, 91, 94, 99, 107, 153, 179, 181-2, 237, 240-1, 244, 246, $249,271,318,332-3$

economy firms, 9, 84, 93

market currencies, 29

market enterprises, 81, 100

market MNEs, 18, 22, 30-2, 34, 36, $39,41,44$

markets, 13, 14-15, 18, 21-4, 26, 29-34, 36, 38-40, 42-6, 47-9, $52-3,60,65,74,80-2,99-100$, $126,137-8,143,148-9,152-3$, 181, 184-5, 219-20, 290, $316-18,320,331-3,355,357-8$

Russian multinationals, 10, 180-1, 189, 204, 215, 217

empirical

analysis, 101, 133, 151-2, 257, 313, 333,365

studies, 79, 102, 104, 138, 260, 263, 276

employment, 32, 153, 260, 268, 270, 272, 274, 277-9, 285-6

EMU (European Monetary Union), 85

endangered koalas, 11, 274, 277, 280-1

Enderwick, P., 6, 184

enterprises

medium-sized, 8, 187, 333

medium-sized regional, 194

state-owned, 34, 36, 156, 227

entrepreneurs, 115-16, 127, 241, 282

entry mode, $39,104,159,176,227$,

243, 294, 316-17, 319

choice, 104, 173, 176, 317, 332-3

environment, 32, 81, 105, 110-12,

$114,123,259,273,302,307,320$

dynamic, 110

host-countries, 352

macroeconomic, 83

protectionist, 279

environmental sustainability, 32

equity capital, 161, 174, 254

Ericsson, 323 


\section{PROOF}

Index 373

ERP (enterprise resource planning), 110-12, 114, 119, 127-8

Erramilli, M., 316-17

Eshaghoff, T., 183

Essel Propack Ltd, 65

establishment chain, 114, 116-17, 128 incremental, 118 international, 114

establishment mode, 159

Estonia, 35, 85-8, 92, 131, 196, 200, 284, 293, 296-304, 307

E-strategy model, 135

EU (European Union), 2, 18, 28, 41-2, $55,59,61,83,85-7,89,92,94$, $96,98,141,152,182,193-5,200$, $205,241,245,254,261,270-1$, $290,299,347,352$

countries, 86-92, 95, 97, 254

EU Member States, 2, 85, 182

euro, 2, 41, 69, 72, 83, 91-2, 98, 303

Europe, 27, 59, 72, 75, 84, 94, 163-5, 193, 205, 222-3, 226, 236, 245, 295, 297, 301, 307-8, 311, 321, $327,329-30,346$

European

Central Bank, 98

companies, largest, 189

competitors, 267

countries, 53, 98, 194, 266, 284, 296, 307, 321

firms, 68, 267

Investment Bank, 234

markets, 60, 226, 321, 330, 347

Monetary Union (EMU), 85

multinationals, 130

SMEs, 268

Social Fund, 362

steel market, 207

Eurozone, 2, 85-7, 90-1, 182

Evangelista, F., 108

evolution, 82, 106, 131, 133-4, 225,364

evolutionary

dynamics, 105, 110, 123

theories, 122, 126, 130

exchange rate, 85-6, 93, 139, 141, $147,149,151,153,162,264,299$ adjustments, 152

fluctuations, 299 movements, 85, 100, 149

volatility, 142

existing international networks, 278, 281

experiential knowledge, 221, 294, 313 acquired, 294

expertise, 31, 66, 236

exports, 3, 6, 27-9, 33, 67, 91-3, 109, $116,138-41,143-5,153,163$, $168,170,211,225-6,228,230$, 234, 242, 249-50, 252, 262, 264, $270,285,300,346,349,351-3$

activities, 118, 311, 349

barriers, 131

behaviour, 333

benefit, 347

dynamics, 91

marketing, 129

market selection, 175

orientation, 281

performance, 129,363

promotion programs, 129

revenue, 3

share, 297, 349, 351, 355

strategies, 182, 342

structure, 270

subsidies, 228

tax rebates, 157

exporters, 114, 264, 293

exporting, 116, 133, 135, 159, 299, $307-8,316,318,321,327,347$, $349,352-3,355,357$

externalization, 286

factor endowments, 315

Faiola, A., 2

FAW (First Automobile Works), 232-3, 236

FDI (foreign direct investment), 6, 14, 17-18, 20-2, 26-30, 32, 34-6, 38-46, 47, 81-2, 85, 99-100, 127, 137-9, 141, 144, 148-9, 151-4, 158-9, 173-8, 218-20, 230, 240-4, 247-50, 252, 254-5, 257, 260-2, 288-90, 314-16

asset-exploiting, 314 efficiency-seeking, 243 inflows, 89, 139, 153, 186, 240, 260-1 
FDI (foreign direct investment) - continued market-seeking, 242 outflows, 15, 149, 247, 249, 254

policies, 35

projects, 20

protectionism, 38, 41, 184

resource-seeking, 262

stocks, 139, 186, 245, 256-7

strategies, 99

Federal Reserve System, 153

Feeny, D., 120

Fernández, Z., 103, 112-14, 125

Fetscherin, M., 154-6, 172

Filatotchev, I., 82

Filippov, 25-6, 43, 182, 184, 219, 262

Fillis, A., 116

financial

institutions, 2, 86, 199, 211, 217, 244

intermediation, 79

leverage coefficient, 276

leveraging, 276

markets, 24, 29, 44, 85, 150

performance measures, 102

regulator, 193

resources, 187, 222, 265, 344

systems, 2, 23, 30

Financial Times, 25, 43, 98

Finkelstein, S., 49, 57-8

Finland, 54, 86, 92, 196, 298, 346,364

firms

accounting, 331

acquired, 49-50, 276

acquiring, 48-9, 56, 66

automobile, 232

biotechnological, 84

blue chips, 269

car-producing, 10

competitiveness of, 80

computer software, 133

entrepreneurial, 258

export-oriented, 341

independent, 231, 236

internationalized, 282, 284, 293

latecomer, 230

private, 26 fiscal decentralization, 223

Fischer, R., 172, 176

Flores, R., 158-60, 170-1, 173

Ford Motor Company, 180

foreign

acquisitions, 82, 97, 177, 189, 192, 194, 204, 216, 276

affiliates, 18, 24, 30, 139, 157, 184, 206, 262

assets, 25, 32, 42, 96, 187, 199-200, 209, 217

companies, 96-8, 192, 207-8, 224, 227, 230-2, 235-6, 286, 319,353

debt refinancing, 188

exchange reserves, 38, 45, 185

firms, 47, 96, 98, 141, 227, 231-3, 259, 273, 285, 306, 327,331

investors, 9, 11, 90, 186, 217, 245, $267,281,283$

market commitments, increasing, $132,176,257,332$

market entry strategies, 331

markets, 2, 12, 53, 82, 109, 115-17, 126-7, 141, 143-4, 148, 183, 192, 199, 206, 215, 217, 242-3, 256, 262, 264, 294, 296, 298, $311,314,316-18,336-7$, $339-40,351,357$

partners, 182, 225, 232, 235-6, 269, $344,355,359$

production operations, 362

reserves, 25, 27, 33, 185

subsidiaries, 183, 188, 308

foreignness

liability of, 48, 155, 158, 241, 257,363

Forrest, R., 182

Forsgren, M., 118

forward vertical acquisitions, 58, 61-3, 66, 79

France, 2, 4-5, 35, 53-4, 86, 88, 92, 97, 130, 194, 196, 211, 224, 231, 236, 272, 296, 321, 347, 351

Freeman, S., 111, 339-40

Froot, K., 141

functional activities, 112

FYR of Macedonia, 42, 96, 277 


\section{PROOF}

Index 375

Gabrielsson, M., 338

Galbraith, J., 113, 121

Gammeltoft, P., 6, 181

García-Canal, E., 48

gas

distribution networks, 194

extraction, 63

producers, 212

Gazprom, 189, 194-6, 200, 212, 216

Gazprombank, 195-7, 207

GDP (gross domestic product), 2, 4, 24-6, 28, 40, 84, 86-9, 94-5, 138-41, 144-7, 150, 168, 179, $185-6,249-52,255,263-4$

growth of, 4, 253, 255, 293

per capita, 89, 249

Geely Holding Group, 180

Genc, M., 84, 158, 320

General Motors, 232-4, 236, 238

geographic distances, 69

geographic proximity, 253, 255

Gerber, S., 116

Germany, 4-5, 53-4, 59, 86, 88, 92, $96,142,167-8,194,196,204$, 206, 211, 219, 224, 233-6, 245, 272, 278, 284-6, 296, 298, 321, $340,344,346,349,352$

Getin Bank, 246

GFCF (gross fixed capital formation), 186-7

Ghana, 167, 198

Ghauri, P., 57, 61, 108, 204, 295, 342

Ghemawat, P., 158

Ghoshal, S., 113, 120

Gibbert, M., 126

Gibraltar, 42

global

business, 125, 130, 186, 312

competition, $65,332,363$

competitiveness, 38, 52, 364

depositary receipt (GDR), 212

economic crisis, 3, 6, 9-10, 43, 100,

180, 184-5, 193, 200, 215-18,

220, 225, 229, 236-7, 241, 270-1

financial crisis, 44, 180, 185, 189, $210,219,232,335,344,346$, $352,357,359,361$

firms, 2, 7-8, 97, 121 growth, 133, 321

industries, 10, 134, 136, 237

market, 14

OFDI, 14, 18-19

players, 31, 38-9, 100, 320, 330

globalization, 8, 27, 32, 100, 104-8, 110-11, 115-16, 120, 122-4, 127-30, 238

Paradox, 13

patterns, 107

process, 9 , 90, 104-5, 107-8, $110-11,114,123,126-7,133$

Globaltrans, 193

Gobo, G., 107

Goldman Sachs, 211

Goldstein, 47, 84, 181

Goodhart, C., 183

Gorenje, 277-9, 284, 287

Gorg, H., 183

Gorynia, M., 240-1

governance

mechanisms, 118

reforms, 47

structure, 131

government, 3-4, 25-30, 35, 39, 73, $75,86,90,95,99-100,109,115$, 151-2, 156-7, 208, 210, 219, 223, 226-7, 229-31, 238, 241, 244, $262,272,276,280,285,327-8$, 360

contracts, 96-7

debt, 25, 87

intervention, 115,145

involvement, 320

national, 41, 67, 179, 183

policies, 46, 52, 124-5, 315, 363

program, 278

rescue programs, 40

stimulus package, 237

Granovetter, M., 339

Great Depression, 1-2, 4, 13, 179

Great Wall, 226, 238

Greece, 2-3, 40-1, 86, 92, 167, 174, 322

greenfield investments, 6, 21-2, 30, 39

Greiner, L., 118, 121

Grewal, R., 292, 294-5, 305-6, 309

Grubaugh, S., 149

Guangzhou, 231 


\section{PROOF}

guanxi, 158, 172-3, 177, 230 based business practices, 178 development, 175 relations, 158

Gugler, P., 154-6, 158, 172

Guillén, M., 48

Guisinger, S., 159-60, 170-1, 173

Gulati, R., 339

Gummesson, E., 295

Gupta, J., 112, 306

Gurvich, E., 187-8

Hadjikhani, A., 293-5

Hagström, P., 118

Haidar, J., 85

Hair, J., 168

Håkansson, H., 120

Haleblian, J., 49, 57-8

Halinen, A., 318

Hangzhou, 323

Hannan, M., 111

Hara, G., 339

Harman, C., 1

Harzing, A., 159, 203

Haunschild, P., 49, 57-8

Hay, F., 10, 222

Healy, M., 114, 117, 121, 127

hedge hogs, 274, 277, 280-1

Heinrich, A., 181

Helsinki, 133, 332, 364

Hennart, J.-F., 57, 257

Herzer, D., 141

Hickson, D., 113

Hidria, 277-8, 287-8

high research-intensive manufacturing, 55, 57, $59,61-4$

High River Gold Mines Ltd, 206

Hitt, M., 48, 112

Hofer, C., 305-6

Hofstede, G., 154, 158-61, 167, $171-3,175-6,178$

Hofstede's indices, 176

Holmquist, C., 293-4

home country, 32-4, 39, 41, 47-8, $51,69,74-5,141-5,149-50,260$, $301,314-16,338,352$

agents, 141

exchange rate, 141 locational advantages, 49

networks, 135

OFDI policies, 32

policy, 32-4, 39

policy framework, 26

policy makers, 34

home market, 30, 116, 137, 159, 247, $271,294,340$

Hong Kong, 157, 164-5, 174, 215

Hopkins, H., 57

horizontal

acquisitions, 58-60, 66, 80

investments, 8, 57, 59, 67-8

strategies, 81

Hornby, G., 104, 116, 131

Hoskisson, R., 47

host countries, 9, 13, 34, 36, 41, 49, $68,75,142,149,153,155,158$, $160-3,165,168,170-2,183$, 242-4, 247-9, 253, 260, 262, 316-17, 327

assets, 141

currency, 141

government, 41

labor costs, 248

market size, 255

HRM (Human Resource management), $103,282,332$

Huettinger, M., 174

Hufbauer, G., 260-1

Hulland, J., 113

human capital, 34, 137-40, 143, 145-50, 267, 308-9

accumulation, 149

development, 143

skills, 149

human resources, 31, 106, 150, 282

Hungary, 85-6, 91-3, 167, 196, 219, 270,285

hybrid engines, 229

Hymer, S., 57, 259

IBM, 287, 321, 329

Iceland, 2, 42, 245

ICT (information communications technology), 19, 102-28, 130,

$132,134,136$

applications, 103

capabilities, 124 
infrastructure, 111

investment, 134

IEI (Internet-Enabled

Internationalization), 135

IFDI (inward foreign direct

investment), 15, 28, 138-9, 149, 250, 252

Ihanainen, O., 114

IJVs (international joint ventures), $116,175,324$

IMF (International Monetary Fund), 4, $26,43,51,81,240$

IMP (Industrial Marketing and Purchasing), 363

incentives, 109, 115, 187, 306

incremental learning, 115

Index of Economic Freedom, 182

India, 4, 8-9, 16, 24, 26-7, 35, 42, $44,49-50,52-4,56,60-1,63$, 67-70, 75, 82, 84, 102, 107-8, $111,125,132,135,138-9,142-5$, 148-53, 181-2, 237-8, 322-3, $352-3$

Indian

companies, 59-60

economy, 27, 139, 148, 150

export activities, 148

export industries, 122

firms, 53, 56, 138, 143-4, 148

GDP, 141

government, 9, 145, 148, 150

MNEs, 26-7, 42, 149-50

OFDI stocks, 140

outward FDI, 26-7, 138, 142, 144, $146,148,150,152,184$

pharmaceutical industry, 153

individualism, 161, 165, 170-3, 177

Indonesia, 4-5, 35, 162, 165, 167, 235

industrial zones, 340, 343, 346

information technology, 33, 130-2, $134-6,150,237,351$

infrastructure, 24, 28, 84, 124, 205

innovation, 18, 29, 124, 130, 132-3, $230,257,265-6,270,275,279$, 282-3, 287-8, 290, 294, 297, 306, $311,325-6,332,352,355,360$, 362

capabilities, 177, 230 instability

financial, 2

macroeconomic, 260

institutional

advantage, 73

environment, 244, 315

frame, 156

legacy, 155

institutions, 44, 90, 100, 187, 244, 258

credit, 86

educational, 307

governmental, 322

local, 132

regulatory, 115

intangible resources, 48, 243, 334

integrated supply chain (ISC), 111, 114,119

integration, 8, 38, 41, 104-5, 111-12, $120,122,124,128,200,283$

intellectual

property division, 145

rights protection, 330

intercultural experience, 115

interfirm cooperation, 131

intermediaries, 117

internal

demand, 187

factors, 11, 137, 317, 334

resources, 317

internalization, 181, 314-15, 330, 361

international

acquisitions, 192

activities, 8, 10-11, 95, 108-9, 117, $120,123,242,292-4,311,314$, $326,331,349$

business research, $6,130,312,363-4$

development, 12, 118, 231

entrepreneurship, 113-15, 127, 129, $134,313,362,364-5$

expansion, 8, 85, 98, 158, 185, 206, $215,230,242,254,318,320-1$, $327,329,333$

experience, 74, 115, 119, 160, 175, 317

investment regime, 41-2

involvement, 337

networks, 274, 278, 280-1, 353

operations, $65,215,244,335-6,341$

production, 137, 257, 268 


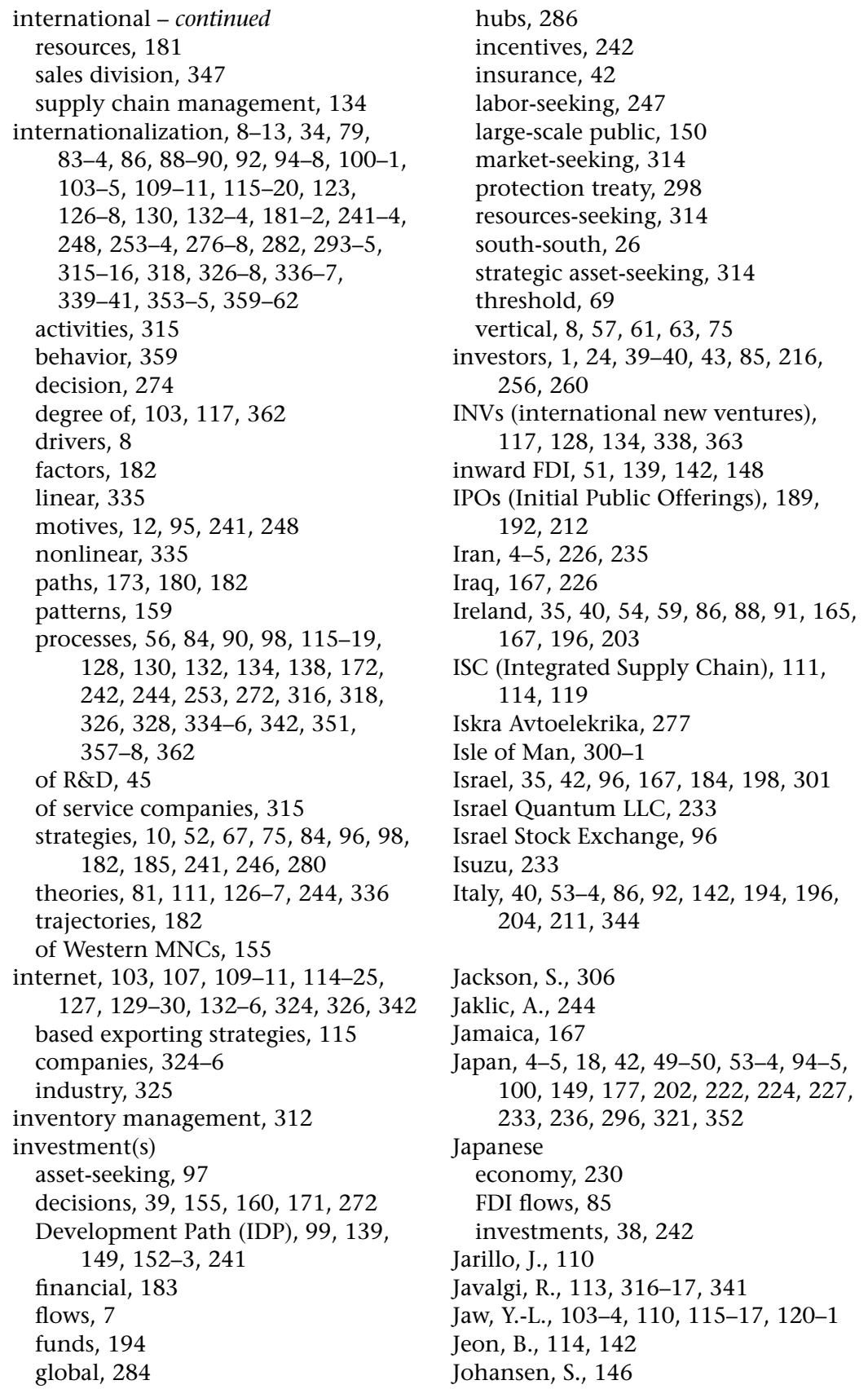




\section{PROOF}

Index 379

Johanson, J., 120, 155, 158-9, 171, $293-5,315,334,335,336,340$

Johnson, C., 227

Jongwanich, J., 85, 94, 260, 283

Juselius, K., 146

Kalotay, K., 25, 47-8, 53, 58, 66-7, 84, $99,181,184,262$

KAMAZ, 196, 208

Kanai, T., 339

Kanjas, K., 120

Kapital, 290

Karatau uranium mine, 201

Karimi, J., 121, 132

Karush, G., 120-1

Kasahara, H., 268

Kaspersky, 318, 320-1, 328-30

Katrishen, F., 315

Kazakhstan, 42, 194, 199-200, 324

Kazanis, P, 103, 126

Kent, R., 162

Keynesian theory, 87

Khanna, T., 149

Kiev, 322

Kim, S., 142

Kirghizia, 174

Kirkman, B., 159, 161

Klein, L., 104, 121

Knickerbocker, F., 243

Knight, G., 115, 120, 337-9, 349

know-how, 57, 209, 232, 234, 236, 243

complementary, 66

operational, 157

superior, 199

tacit, 60

knowledge

deficiencies, 156

development, 132, 176, 257, 332

gap, 138

intensive service firms, 55-6, 79

intensive services, 55-6, 58-9, 61-4, 68

internalization, 122

management, 124

management systems, $118,124-5$

sourcing, 174

transfer, 159

Kogut, B., 144, 158-61, 173

Kogut-Singh index, 158
Kohlhagen, S., 141

Kolektor, 278, 285-7

Kolverid, I., 240

Konsynski, B., 121

Korea, 35, 132, 142, 152, 184

Korhonen, H., 336

Korston Group, 197

Kosmos Association, 196

Kosovo, 277

Kostova, T., 111, 114

Kotha, S., 112

Kovintrade, 277

Kredobank, 246

Krenholm, 293, 298-300, 305, 307-10

Krugman, P., 1

Kueh, S., 149

Kuivalainen, 336, 363

Kumar, N., 27, 52, 66, 79, 144,148

Kundu, S., 117, 120, 315

Kutschker, M., 118

Kuwait, 167

Kvale, S., 126

Kwok, C., 141

Kyrgyzstan, 42

Kyrkilis, D., 141, 143

labor, 243, 306, 315, 320, 325 costs, 237, 244, 247, 249, 252-3 market, 187

Lai, J., 305-6

Lall, S., 84, 142-4, 149

Larimo, J., 155, 158

latecomer disadvantages, 320

lateral rigidity, 117

Latham, S., 292-3

Latin America, 1, 5, 43, 164, 176

Latukha, M., 12, 314, 324, 326

Latvia, 2, 35, 85-6, 88, 92, $167,174,176,196,200,298-9$, 302-4

leadership competences, 283

role, 267

learning process, 114, 232

Lebanon, 167

Lecraw, D., 84

Lengeard, E., 316 
Leonard-Barton, D., 341

Lesotho, 174

leverage, 48, 65, 109, 134, 181, 230, 337,351

leveraging, 73, 226, 243-4

liability of outsidership, 257, 363

liberalization, 38, 47, 144, 150, 283, 287

Libya, 3

Lindqvist, M., 337

Linux Solutions, 321

Lipnik, K., 286

liquidity, 30, 209, 255

constraints, 260

crisis, 186

problems, 200

shortfall, 179

Lisbon, 132

Lisitsyn, N., 84

Lithuania, 85-6, 88, 92, 174, 176, 206, $245,298-9,302-4$

Liuhto, K., 182, 320

Liu, L., 231

Liu, X., 149

Ljubljana, 285, 288-91

LLL paradigm, 181

Loane, S., 112, 114, 119-20, 124-5, 127

location advantages, 90, 314

choices, 151, 159-61, 176

competitiveness, 89

decisions, 125, 159

Lowell, B., 261

low research-intensive manufacturing, $55-6,59,61-4$

Ložar, B., 287

LSE (London Stock Exchange), 212

Lübbe, H., 104

Luganskteplovoz, 202

Luhmann, N., 104

Lukoil, 63, 72, 195, 197, 205-6, 212, 221

Lummaa, J., 338, 349

Lundan, 48, 61-2, 67

Luo, 6, 13, 47-8, 50, 65-6, 74, 81, 84, $100,103-4,117-18,133,158$, $177,319,332,365$

Luostarinen, R., 117, 334, 336, 338

Luxembourg, 86, 88, 245
M\&A, 6, 8, 21-2, 27, 30, 48-50, 53, $186,243,248$

cross-border, 21, 27, 30, 187

total value of, 21

Macau, 164, 174

Macharzina, K., 118

macroeconomic

advantages, 84

conditions, 243

determinants, 138-9

Madsen, T., 337-8, 340

Magna International, 209

Magnitogorsk Iron and Steel Works, 206

majority ownership, 287

Makhija, M., 183, 292, 306

Makino, S., 143

Malaysia, 162, 165, 167, 235, 296, 343

Malaysia outward FDI, 152

Malnight, T., 118, 120

Malo, S., 84

Malta, 86, 88, 92, 167

management, 44, 78, 81-2, 102-3, $105,114,116,135,175-6,196$, 202-3, 219-21, 238, 257, 262, $265,269,273-5,277,281-3,289$, 297, 302, 307, 309, 311-13, 317, 364

buyouts, 276

capabilities, 227, 294

characteristics, 317

competences, 280

crisis, 274

dimensions, 122

Information Systems, 112

practices, 19

processes, 112

managing director, $61,63,65$

Manrakhan, S., 110, 120

manufacturers, 65, 202-3, 223-4, 226, 228-9, 231, 235-6, 293, 342-4, 347

manufacturing, 5, 10, 19-20, 26-7, 50, $53,56,63,195-8,210,222,262$,

$313,315,322,327$

activities, 222

assets, 194

base, 222 
capabilities, 227

companies, 265, 284

enterprises, 133, 343

facilities, 224

research-intensive, 55, 59-62, 64

manufacturing firms, 107, 109, 112, 270, 290

high research-intensive, 55, 79

low research-intensive, 55,79

research-intensive, 55-6, 79

Maoist period, 222-3

Marinova, S., 1, 7, 84

Marinov, M., 1, 7, 84

market

access, 230

changes, 273

conditions, 294

economies, 230, 240, 267, 269

entry mode, 317

entry strategy, 331

exit, 335

failures, 81

knowledge, 318

leader, 320, 329

openness, 144

orientation, 84

power, 57

price, 300

segments, 308, 311

selection, 173

share, 2, 97, 216, 228, 231, 238, $272,302,304,316,324$

size, $49,56,127,168,244,247$, 252-3

success, 73

value, 216

marketing, 133, 273, 285, 299, 301, 308, 330, 343, 362-3

capabilities, 339

know-how, 315

Markusen, A., 110

Markusen, J., 143, 149

Marquardt, D., 168

Marschan-Piekkari, R., 131, 312

Marshall, R., 158

Martín Martín, O., 159

Marx, 13

masculinity, 161, 170-3 scores, 168
Mathews, J., 47-8, 113-14, 117-21, $127,181,230,231,253,256$

Mattsson, L.-G., 334, 336

Maxton, G., 238

Mazda, 233, 236

MBOs (management buy outs), 265, 269-70, 273-6, 281, 286

McAllister, G., 7, 14

McAuley, A., 339

McDougall, P., 115, 116, 120, 337-9, 340, 349

McKelvey, B., 111

McMahon, P., 104, 120

Mechel, 197, 207-8, 221

Meissner, H., 116

Melbourne, 364

Mercator, 277-9

Merkur, 273-4, 276, 284

Merriam, S., 126

Mexico, 165, 167, 184, 235, 346,349

Meyer, K., 143

Michailova, S., 84

Middle East, 95, 286, 322

Milelli, C., 10, 222

Miles, M., 341

Miller, D., 118, 121

mindset, 32, 106, 109, 113, 114, $115,117,120,124,127$, 288, 354

global, 134, 282, 338-9

managerial, 127, 282

minority stakes, 192, 200, 217

Mirax Group, 200

MK Založba, 284

MNCs (multi-national companies), 48, 56, 154-5, 173, 219, 243, 246-7, $256,281,284$

MNEs (multi-national enterprises), 14, 17-20, 24, 27, 29, 31-2, 39, 41, $100,130,132,142,259-60$, 262-3, 268, 271-2, 274, 277, 279, $282,287,319-20,331$

family-controlled, 31

non-financial, 26

mobile operators, 301

models of development, 223, 229

Moen, Ø., 104, 112-14, 121, 337 
MOFCOM (Ministry of Commerce), $157,160,166,174,177$

Moini, H., 117

Moldova, 96, 195

Mongolia, 198

monopolistic advantages, 66-7, 152

monopolistic rents, 66

Montenegro, 42, 85, 96, 197, 217

Montgomery, C., 57

Morck, R., 73, 154, 156, 170

Morgan-Thomas A., 104, 117

Morocco, 35

Morris, S., 145

Moscow, 3, 43-4, 211, 215, 320-2, 344,346

motivations, 74, 79, 109, 150, 162, $175,178,182,243,314,320$

motives, 6, 8, 74, 94-5, 97, 108, 194, 218, 241-4, 246, 280, 317, 326,335

Motorola, 323

Mrak, M., 269

Mukherji, A., 121

multinational companies, 80, 99, 179, 181-3, 187, $192,211,215-17,219,256,315$ enterprises, 43-5, 80-2, 99, 130, 132, 142, 151, 175, 219, 257, $259,290,333$

firms, 7-11, 91, 93-4, 99, 176

Mumbai, 323

Munro, H., 116, 339

Murphy, G., 114

Myanmar, 174

Nakashima, 13

Narjoko, 183, 220

Narula, R., 84, 137-9, 143, 148, 181,218

NASA, 284

NASDAQ, 96

national

companies, 223

culture, 158, 161-2, 176-7, 315

currency devaluation, 185, 204

economy, 1, 8, 42, 210-11, 216, 227,282

firms, 81, 289, 326

industries, 55
National Bank of Poland, 245-6, 250

National Bank of Ukraine, 2

National Innovation System, 153

Natural Gas Corporation Limited, 26 natural resources, 19, 27, 32, 35, 56, $154,156,168,247-8,252,314$, $319,326,331$

NDRC (National Development and Reform Commission), 157, 227

negotiations, 209, 282

Nepal, 174

net

debt, 208

loss, 303

profits, 189, 296-7, 301-3, 342

Netherlands, 5, 35, 54, 88, 92, 142, $165,167,194,199,201-2,204-5$, $234,245,321,346$

network, 60, 93, 103-4, 106, 110-11, $118-21,123,128,131,134-5$, 207, 211, 217, 230, 288, 339, 346, $352,354,360,364$

approach, 336, 363

based MNC structures, 133

development, 115

leverage, 104, 120

linkages, 151

location, 363

partners, 339

relationships, 294

theories, 126-7

networking, 334, 339-40, 363

capability, 120

global, 105, 111, 119

New Delhi, 153, 322

new markets, 59-60, 139, 157, 188, 260-1, 266, 268, 273, 280, 302, $311,314,339-40,355$

New Model for Global Growth, 133

New Triad, 7, 18-19

new ventures, 133, 271, 337

international, 117, 131, 134, 338, 363

New Zealand, 8-9, 35, 42, 102, 107-8, 111

Nguyen, T., 118, 122-3

Nieto, M., 103, 112-14, 125

Nigeria, 167

Niosi, J., 56, 60 


\section{PROOF}

Index 383

Nissan, 233, 236

nonlinear internationalisation, 364

Norburn, D., 338

Nord Gold, 207

Norilsk Nickel, 193

North Africa, 322

North America, 49-50, 53-4, 94-5, 164, 208-9, 322, 343-4, 347, 352-3

North Western Europe, 205

North-Western Oil Group, 197

Norus, J., 84

Norway, 42, 54, 167, 197, 245

Novatek, 200

Novell, 321

Novorossiysk Sea Trade Port, 198

Nummela, N., 113-14

NYSE (New York Stock Exchange), 215

Obloj, K, 10, 240-1, 253

Oceania, 164

ODA (Official Development Assistance), 43

ODE (Original Design Engineering), 65

ODM (Original Design Manufacturer), 347

OECD (Organization for Economic Cooperation and Development), $24,35-6,44,51,53,67,81$, 143-4, 153, 181, 220, 256, 258, $263,284,290$

countries, 98, 284

OEG (Olympic Entertainment Group), 300, 302-5, 307, 309-10

OFDI (outward foreign direct investment), $6-8,14-15,18$, 25-34, 36, 38, 44, 46, 47-52, 73, 81-2, 85, 95, 98-9, 101, 137-9, $141-55,160,163,168,173$, 175-7, 218-20, 240-2, 257, 260, 320

flow, 15, 17-18, 24, 26-9, 31, 34, 53, 155

stock, 20, 25, 27, 29, 139-40

official development assistance (ODA), 43

offshore outsourcing, 268

ÖKO-TEX, 296, 300
Old Triad, 18

OLI (Ownership, Location and Internalization), 242, 257, 314, 329-30

framework, 242, 314-15

paradigm, 181

Open Door policies, 34, 156

operating cash-flows, 72

operational efficiencies, 265

operational results, 279

Oracle, 323

organisational

ecology, 129

evolution, 135

flexibility, 283, 291

practice, 132

resources, 102, 112

Original Design Engineering (ODE), 65

original equipment manufacturer

(OEM), 343, 353

Oslo, 130

output linkages, 151

outsourcing, 19, 122, 268, 273

Overby, 119, 134

overseas

activities, 95

business development, 355

operations, 317-18

Oviatt, B., 115, 116, 337

ownership, 181, 207, 210, 217, $242,260,269,276,289,315$, 327,329

advantages, 9, 48, 66-7, 137-8, 150, $181,183,220,241,260,314$, 329

structure, 182, 269, 287

Oystein, M., 316

Palepu, K., 150

Paloni, N., 143, 149

Palvia, P., 120

Panama, 198

Pananond, P., 48

Panibratov, A., 12, 25, 84, 314, 320

Pantelidis, P., 141, 143

Paraguay, 174 
partnership, 230, 236, 318, 321-5, $327,329,331,339,361$

passive globalizers, 116-17

Patton, 107, 134

Pecotich, A., 339

Peng, M., 48, 156

pension funds, 188

performance

long-term, 80

strong, 206

superior, 260

Perkins, J., 1

perspectives

contingency, 332

dynamic capabilities, 313

emerging supply chain, 110

entrepreneurial, 254

industrial organization, 57

information processing, 103

international supply chain, 119

life cycle, 112

micro-economic, 180

Peru, 198

Petersen, B., 121, 127

Petrokommerts, 195

Petrol, 277

Petrou, A., 48

Petrov, S., 287

pharmaceuticals, 56, 66, 79, 150, 195-6, 243

PIK Group, 195-6

Piscitello, L., 122

Pla-Barber, J., 317

Playtech, 295, 300-1, 304, 307, 309, 310

Podjetja, 288

Poland, 2, 10, 35, 85-6, 88, 91-2, 95, 217, 240-1, 245, 247, 254, 257, $285,296,302,304,321,324$

policies anti-crisis, 188

contract rights enforcement, 244

corporate, 317

domestic, 9

incremental, 226

market-oriented, 47

national, 33

public monetary, 1 policy

context, 44

dilemma, 33

framework, 32-3, 42

implications, 44, 180, 259

responses, 180, 183-5, 187, 219

Polish

banks, 246

capital, 246

casinos, 304

companies, 98, 244-5, 248, 254, 256

FDI, 245, 253, 255

firms, 95, 241

investments, 245

investors, 240, 245, 253, 255-6

managers, 253

market, 96, 256

Ministry of Economy, 256, 258

OFDI, 10, 241-2, 246, 248-9, 254

political

democracy, 240

risk, 39-40, 44, 168, 253

risk insurance, 44

Porter, M., 103, 113

portfolio investment, 30

Portugal, 35, 40, 54, 86, 92, 167, 183, 197

Poslovni Dnevnik, 277, 287, 289

Poulis, K., 107

Powell, T, 113, 120, 125

power, 3, 173, 189, 225, 237, 262, 267, 284,329

distance, 161, 165, 170-3

Pradhan, J., 27, 143, 184

Prague, 322

Prahalad, C., 113

Prašnikar, 288-91

PRC (People's Republic of China), 173

Prikarpattya Bank, 246

Primerod International Ltd, 200

privatization, 269, 280, 295

privatized firms, 265

proactive approaches, 261, 274, 280

product

adaptation, 242

design, 308

expansion strategies, 323

innovation, 265 
production

capacities, 65, 300, 323

costs, 300, 358

networks, 182

technologies, 79, 337

productivity, 143, 266, 269, 289

profitability, 49, 73, 87, 93, 102, 142, 189

negative, 192

reduced, 30

promotion, 34, 230, 271, 355, 359-60

property

intellectual, 66

private, 222

protectionism, 38, 185, 234

Prugel, T., 149

psychic distance, $115,119,158-9$, $175,178,244,248,257$

pull factors, 74

quality certificate, 300

Quantech Global Services LLC, 65

Quelch, J., 104, 121

R\&D, 45, 178, 195, 230, 265, 268, 272-3, 279, 281, 306, 355

Rabbiosi, L., 8, 47, 67, 69, 74

Ramamurti, R., 42, 44, 84, 181

Rani, U., 111

Rantapusca, T., 114

Rao, H., 121

Rasiah, R., 320

ratio

current, 72-3

fixed capital, 276

public expenditure, 88

solvency, 72-3

raw materials, 66, 157, 293, 300

recession, 4, 28, 41, 45, 184, 218, 261, $272,279,290,292,305,311-12$

recovery, 4-5, 38-9, 217-18

re-entry, 335, 340-1, 353, 355-7

regionalization strategy, 154

regional multinational enterprises, 100

regulations, 34, 65, 157, 310

re-internationalization, 12, 294, 309, $335,341,351,353,361$ relationships, $57,65,120,123,138$, $146,148-50,152,172,230-2$, $273,336,339,363$

capital market, 141

co-integration, 146

complementary, 112

contractual, 316

direct causal, 149

established, 321

improved customer, 266

personal, 173

vendor, 323

reliability, 103, 108, 113-14

Renault, 285

Renova Group, 210

Repovž, 285, 290

Republic of South Africa, 211

reputation gap, 258

research interests, 334

resilience, 14, 29, 205, 216

resource, $26,48,64,67,109,115,124$, $135,137,156,168,181-2,194$, 205, 208, 229, 242-3, 246-7, 266, 286, 294, 297, 305, 312, 315-17, $320,337,339,341,351$

allocation, 230

based industry, 55-6, 59, 61-4, 68

based view (RBV), 316

commitment, 294

company-level, 317

endowment, 103, 115

gap, 258

network, 363

proprietary, 314

restrictions, 125

rich countries, 56-7

seekers, 247

unique, 314

Rhee, J., 294

Rhee, S., 142

Rialp, A., 338, 340

Rindova, V., 112

risk management, 283, 288, 312

RMB, 28, 224, 229, 236, 343

Rocha, V., 183, 260

Rodrigues, S., 116, 155-6, 181, 320

Rodrik, D., 1

Rojec, M., 84

Romanelli, E., 118 
Romania, 85-8, 91-2, 96, 194, 197, $205,302,304,321-2$

Ross, C., 292-3, 306

Rosson, P., 117

Rugman, A., 47-8, 67, 93, 154, 164, 172,315

Ruigrok, W., 126

Rui, H., 73, 156

Rusal, 215

Rushydro, 212

Russia, 3-4, 8, 23-6, 35, 43-4, 45, 49, 51-4, 56-7, 59-61, 64, 67, 69-70, $72,75,82,85,94-5,177-89,200$, 206, 208, 212, 215-16, 218-21, 278-9, 319-20, 322, 324-5, 344

Russian, 58, 63, 72, 82, 84, 185, 187-9, 192-5, 198-9, 205, 207-12, 216-19, 273, 314, 316, 318-20, 322, 324, 326-8, 330-2 acquisitions, 53, 55, 194 aerospace MNCs, 332

companies, 69, 181-2, 184-9, 192-4, 199-200, 204, 209-10, 212, 215-17, 219, 319, 322

Development Bank, 216 economy, 25-6, 180, 185-7, 216, 320,326

Federation, 26, 42, 44, 50, 163, 219

firms, 52, 55, 84, 192, 318-20, 327, 329

government, 10, 52, 180, 185, 187-8, 199, 204, 210-12, 216-17, 328

investments, 217-18, 327

market, 210, 325

MNEs, 26, 32, 100, 318-20, 327,331

multinationals, 9-10, 180, 182, 184-5, 189, 192, 194, 200, 208, $215,217-18,327$

OFDI, 25, 320

oil, 204-5, 216

service companies, 327-8

software companies, 328

stock market, 185, 193

Trading System (RTS), 211

Russkie Mashiny, 208
SAIC (Shanghai Automotive

Corporation), 233, 236

sales

department, 347

promotion activities, 273

revenues, 324

subsidiaries, 307

Salidjanova, N., 85, 95

Samarakoon, I., 85

Samiee, S., 104, 115

Samii, M., 120-1

Sanchez-Peinado, E., 317

San Diego, 135

San Francisco, 133

Sao Paulo, 271

Sauvant, K., 7, 14, 35-6, 47-8, 52-3, $55,84,154,181,184,218,240-1$, $244,254,262$

Sberbank, 195-6, 209, 216, 221

Scabini, P., 340

Schuknecht, L., 89

Schuler, R., 306

Schulz, A., 104

Schwartz, S., 161

Scordis, N., 315

Serbia, 42, 85, 96, 197, 286

Servais, P., 316, 337-8, 340

Service(s)

after-sales, 148

cleaning, 283

communication, 55

companies, 315-16, 331

firms, 109, 112, 317, 332-3

industries, 53, 327, 332

insurance, 200

internet security, 321

legal, 243

marketing, 317

online, 103

sector, 18-20, 56, 135, 243, 295, 315,333

Severstal, 192, 195-7, 206-7, 221

Seward, L., 249, 253

Shama, A., 293, 306

Sharma, D., 112, 316, 333, 339

Shenkar, O., 126, 159, 161

Shenzhen, 229

Shi, Y., 10, 222

Sicily, 206 
Siddarthan, N., 143

Siegfried, J., 65, 82

Siemens, 323

Silicon Valley, 324

Silovye Mashiny, 198

Simon, A., 293

Simon, H., 262

Sinani, E., 143

Singapore, 8-9, 102, 107-8, 110-11, $115,125,142,164-5,167,343$

Singh, H., 42, 57, 84, 159, 161, 162, 173,181

Singh, J., 100

Singh, N., 117, 120

Sivakumar, K., 316

Skovgaard, L., 260-1

Slangen, A., 154, 158-9, 161-2, 173

Slovakia, 85-6, 88, 92, 96, 197, 302, 304

Slovene

economy, 259, 263-4, 268-9, 282

enterprises, 267-8

firms, 264, 267-9, 271, 280, 284-5, 287, 289

managers, 267

market, 277

MNCs, 263, 277, 279-80, 284, 286

MNEs, 259, 266, 268, 270-2, 279, 281-2, 286-7

multinationals, 286

outward FDI, 270

SMEs, 268, 285

Slovenia, 35, 44, 85-6, 88, 91-2, 96, 184, 219, 244, 263, 265, 267, 270-1, 273, 278-80, 284-6, 288-90

Slovenian Statistical Office, 287

(SMEs) Small and Medium-Sized Firms, 102, 104, 106, 108, 110, $112,114,116,118,120,122,124$, $126,128,130,132,134,136$

born global, 339, 361

e-commerce experience, 131

internationalization theory, 135

Smrekar, T., 277

social

consequences, 3

systems, 104-6, 122, 127, 132

welfare, 28
SOEs (state-owned enterprises), 34, 36, 156, 227, 229, 232, 236, 238

software

industries, 60, 321, 327

market, 322

producers, 330

solar energy, 210

solutions provider, 65

South Africa, 4-5, 174, 235

Southeast Asia, 1, 322

South-East Europe, 42

South-South FDI, 6

Sovdat, 276, 286, 290

sovereign wealth funds, 36,154

Soviet Bloc, 84

Soviet market, 295, 298

Spain, 35, 40, 54, 86, 88, 92, 96-7, $135,197,206,344,347,351$

Spanish banks, 331

Special Economic Zones, 227

Spence, M., 294

spillover effects, 32

Sri Lanka, 174

Stabilization Fund, 26

Standifird, S., 158

state

assets, 157

budget, 87-9, 97

capitalism, 45

corporation, 187

State Economic and Trade

Commission, 157

Stein, J., 141

Stevens, G., 141, 153

Stiglitz, J., 283

stock

exchanges, 86, 98, 215, 298

market interdependence, 100

market speculation, 157

Stöttinger, B., 158

strategic

alliance, 273, 306, 325, 340

resources, $60,243,247,249,252-3$

strategies

current, 295

defensive, 277

de-internationalisation, 363

differentiated, 184

offensive, 278 
strategies - continued

proactive, 262

regional, 164

turnaround, 312-13

structural reforms, 276

Sub-Saharan Africa, 175

subsidiaries, 93, 97, 116-17, 132, 141, $145,183,194,212,234,236,278$, 294, 297, 301, 316, 319, 322, 325

Sudarsanam, S., 305-6

Sundqvist, S., 336

suppliers, 120, 122, 190, 242, 278,

$284,297,306,336,353,358$

supply chains, 111-12, 119, 307

Surgutneftegaz, 189, 196

survival strategy, 266

sustainable

solutions, 114

value enhancement, 66

Sutyrin, S., 100

Svenšek, K., 284

Svetlicic, M., 244

Sweden, 35, 54, 86, 88, 165, 167, 234, $245,296-9,321,346,349$

Switzerland, 35, 42, 54, 130, 174, 194, 197, 204, 245

Syria, 3, 226

Tadzhikistan, 174

Taiwan, 130, 132, 198

Takagi, S., 85

Tallinn Stock Exchange, 302

Tanzi, V., 89, 99-100

target financing, 311

Tatneft, 212

taxes

excise, 98

gambling, 304

indirect, 98

tax rates, 91

corporate, $26,83,90-1,300$

tax system, 205

technical expertise, 236

technological

advancements, 19

advantages, 143, 183

agglomeration, 122

gap, 89

leapfrogging, 79 resource base, 248

solutions, 278

Teece, D., 293-4

telecommunications, 67,150 , 194-5, 197

equipment, 322

Thailand, 162, 167, 235

Third World Enterprises, 99

Third World Multinationals, 101

Thomas, D., 48

Thorelli, H., 110

Timan-Pechora, 205

Tong, S., 158, 178

Törnroos, J., 318

Toyota, 232-3, 236

trade

barriers, 242, 244

deficit, 244

fairs, 109, 117, 297, 307, 344

flows, 173

liberalization, 144

networks, 137

sector, 144

Trade and Industry Bureau, 342

transaction cost advantage, 178

transformation

economic, 84

organizational, 130

transition, 82, 99-100, 133, 181, 218, $220,257,263,267-9,271,288$, 312,320

economies, 15, 42, 81, 100, 261, 288

Transneft, 189

transport industry, 323

Trimo, 277, 284, 286-7

Tung, R., 6, 47, 50, 65-6, 74, 84, 161, 178,319

Turkey, 23, 35, 96, 174, 184, 200

Turkmenistan, 42, 174

Tushman, M., 118, 135

Ukraine, 42, 85, 174, 194-5, 199-201, $204,211,235,245-6,278,302-3$, $309,322,324-5,353$

(UK) United Kingdom, 4, 59, 80, $82,88,100,142,149,168,194$, 204, 206, 220, 296, 301, 312, 321, 352,364 


\section{PROOF}

Index 389

uncertainty avoidance, 155, 161, 165, 170-3

UNCTAD (United Nations Conference on Trade and Development), 6-7, $13,15,18-24,26-8,30-1,37,42$, $45,47-8,52,82,94-5,100,140$, $153,174,178,181,186,220,243$, $258,261,270$

UniCredit Bank, 246

United Arab Emirates, 296

United Company Rusal, 215

UN (United Nations), 82, 100, 160, 178,220

Uppsala model, 131, 244, 253, 257, 312

Uralkhim, 196

Uralsib, 196

Uralvagonzavod, 196

Urbas, U., 277

Uruguay, 167, 174, 235

USA (United States of America), 4, 63, $135,141,149,162,194,197,204$, $211,223,233,236,296,298,307$, $330,340,343$

US (United States), 28, 36-7, 42-5, 54, $58-9,152,164,224,226,238$, $321,343,347,349$

banking system, 179

bonds, 263

location choices, 160

manufacturing enterprises, 132

manufacturing industries, 152-3

Uzbekistan, 42, 174, 195

Vahlne, J.-E., 115, 132, 176, 257, 312, 316,332

Vahtra, P., 181-2, 320

validity

analytical, 126

external, 126

internal, 126

value, $2,17,21-2,24-5,45$, $53,55,89,91-3,95,98,119,136$, $142,146,155,157,159-60,172$, $176-7,185,187,193,201-2$, 205-6, 209, 243-4, 252, 270, 283

added activities, 80 appropria, 258

chain, 58, 122, 125

van Den Bulcke, D., 43

Vandermerwe, S., 314

variables

dependent, 147, 160, 168, 170

explanatory, 138-9, 146, 168, 173

independent, 145-6, 161, 168, 249

Varum, A., 183, 221, 260

Vektor, 274, 276

Venezuela, 165

Verba, C., 320

Verbeke, A., 159, 161, 315

Veritas Energia, 202

Verma, R., 9, 137

Vernon, R., 121, 135

Viator, 274, 276

Vietnam, 134, 167, 226, 235, 352

Vissak, T., 292, 335, 341

volatility, 142

environmental, 313

political, 3

Volkswagen AG, 231

Volvo, 233-4

Voss, H., 170

VTB Bank, 194, 207, 216

Wade, M., 113

Wagner, B., 116

Wang, H., 231

Wang, J., 294, 306

Warsaw, 45, 221, 257-8, 290

Washington, 43-5, 81, 152-3, 290

Wasowska, A., 10, 240

Weerawardena, J., 293

Weiss, M., 277

Welch, C., 294, 335, 341

Welch, L., 131, 294, 334-6, 341

Wells, L., 84

Wendre Scandinavia AB, 296

Wennberg, K., 293-4

West Africa, 161, 207

Western Balkans, 272, 286

Westney, D., 111, 114

Wheeler, M., 149

Wiedersheim-Paul, F., 155, 158-9, 171

Wilinski, W., 8, 83, 84, 95

Wilkins, A., 341

Wilkinson, I., 119 
WIPO (World Intellectual Property Organisation), 162, 178

Wisniewska, I., 26

Woodward, J., 102

World Bank, 18, 30, 45, 160, 174, 178, 240, 290

Development Indicator, 162

World Investment Report, 13, 45, 82, $100,143,153,178,220,258$

Wormald, J., 238

Wright, M., 48

WSE (Warsaw Stock Exchange), 95-7, 101

WTO (World Trade Organization), 163, 170-1, 223-4

Wu, L.-Y., 48, 293

Yamin, M., 107

Yandex, 325
Yin, R., 126, 135, 295, 341-2

Yip, G., 73, 156, 182

Young, S., 129

Youssef, A., 143, 149

Yugoslavia, 263-4, 267, 270, 290

Zagreb, 279

Zaheer, S., 110, 120, 159, 161

Zambia, 198

Zander, L., 172, 253, 256

Zelenograd, 322

Zettinig, P., 335

ZGG Cayman Holding, 200

Zhang, C., 111

Zhang, K., 143, 149

Zhang, X., 12, 334

Zhao, Z., 232

Zucchella, A., 340

Zupan, N., 268 